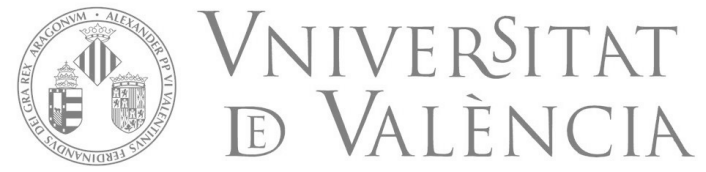

\title{
Present problems to the Right to Peaceful Public Assembly in Spain
}

\section{Authors:}

1. Alejando Año-Ibiza

2. Marcos Diago-Sanz

3. Olga Lenzi

4. Lorena Mercader-Jiménez

5. María Dolores Núñez-Ávila

6. Paula Quintana-Nieto

\section{Supervisor:}

1. Andrés Gascón-Cuenca, Ph. D. 


\section{O) OPEN SOCIETY \\ C JUSTICE INITIATIVE}

(C) Open Society Justice Initiative. All rights reserved.

This report has been founded by Open Society Justice Initiative. Nevertheless, the content of this document may not represent the official views or policies of Open Society Justice Initiative.

Clínica Jurídica per la Justícia Social | Informes ISSN: 2386-9860

DOI: $10.7203 /$ clinicajuridica. 15142 
1. Introduction 4

2. Spanish Legal Framework 5

2.1. The guarantees of the right to Peaceful Public Assembly settled by the Spanish Constitution 5

2.2. Constitutional Standards of Protection of the Right to Public Assembly. 7

2.3. Definition of the right to peaceful public assembly 10

2.4. Spanish Constitucional Court Case-Law 11

2.5. Article 513 and 557, Criminal Code 13

2.6. Private Security Services Act 13

2.7. Public Safety Organic Act 4/2015 17

$\begin{array}{ll}2.8 \text { Peaceful Public Assembly Regulatory Act } & 18\end{array}$

3. International standards of protection of the right of peaceful assembly 20

3.1. The Human Rights Council 21

3.2. The International Covenant on Civil and Political Rights 22

3.2.1. Human Rights Committee reports, regarding article 21.

3.3. European Convention on Human Rights (ECHR) 24

3.3.1. Article $11 \quad 24$

3.4. Interpretation of article 11 by the European Court of Human Rights 26

A. Prescribed by Law 28

B. Pursue a legitimate aim 29

C. The principle of proportionality 33

D. The Margin of Appreciation 35

E. The requirement of prior authorization. 36

$\begin{array}{ll}\text { 4. Conclusions } & 38\end{array}$

Annex I. News dossier $\quad 40$

News from 2013

News from 2014

News from 2015

News from $2016 \quad 61$

$\begin{array}{ll}\text { Interactive map of news } & 71\end{array}$ 


\section{Introduction}

The Public Safety Organic Act 4/2015, also known as Spanish "gag law", has been harshly criticized by both national and international experts, and several worldwide institutions, due to the fact that it may be considered contrary to human rights and fundamental freedoms.

This report focuses on the identification of the standards of protection of the right to peaceful public assembly and the challenges this new regulation poses to it. Therefore, we will cover the following areas:

On the one hand, we shall analyze the Spanish legal framework, that includes the following:

1. Article 21 of the Spanish Constitution, which offers a special protection to the right to peaceful public assembly.

2. The constitutional standards of protection.

3. The problem of the definition of this right.

4. The case-law of the Constitutional Court, in order to identify the standards of protection set by it.

5. Articles 513 and 557 of the Criminal Code.

6. The Private Security Services Act, as it regulates some aspects that may interfere with fundamental rights, as the one we are studying in this report.

7. Finally, we will analyze the regulation established by the new Public Safety Organic Act, entered into force in 2015, and also the Peaceful Public Assembly Regulatory Act.

On the other hand, we will research into the international standards of protection of the right to peaceful public assembly, which are mainly settled in three international legal instruments: The Human Rights Council, the International Covenant on Civil and Political Rights, and the European Convention on Humans Rights, and its case-law.

Finally, we shall conclude this report with a critical approach to the new regulation established by the Public Safety Organic Act, as we consider it precludes the standards of protection we will identify throughout the report. 


\section{Spanish Legal Framework}

In this part of the report, we will focus on the protection of the fundamental right to peaceful public assembly in the Spanish Legal Framework. In order to analyze its protection, firstly we will study the guarantees and standards of protection recognized in the Spanish Constitution. Thereupon, we will establish a definition of the right to Public Assembly and we will examine the Spanish Constitutional Court case-law. After that, both the Private Security Services Act and the Public Safety Organic Act 4/2015 (from now on, PSOA) will be studied; and finally, we will examine Articles 513 and 557 of the Spanish Criminal Code.

\subsection{The guarantees of the right to Peaceful Public Assembly settled by the Spanish Constitution}

The Spanish Constitution (here in after CE), passed in 1978, protects the fundamental right to peaceful public assembly in its article 21, which states that:

1. The right to peaceful unarmed assembly is recognized. The exercise of this right shall not require prior authorization.

2. In the event of meetings in public places and of demonstrations, prior notification shall be given to the authorities, who may ban them only when there are well founded grounds to expect a breach of public order, involving danger to persons or property.

Article 21, due to its consideration as a Fundamental Right, the Spanish Constitution guarantees to it a particular protection, set in the article 53.2 CE. This article establishes that:

2. Any citizen may assert his or her claim to the protect the liberties and rights recognized in Article 14 and in Section 1 of Chapter Two, by means of a preferential and summary procedure in the ordinary courts and, when appropriate, by submitting an individual appeal for protection («recurso de amparo») to the Constitutional Court. This latter procedure shall be applicable to conscientious objection as recognized in Article 30. 
Firstly, it is possible to find a protection by means of a preferential and summary procedure before the ordinary courts. It is a judicial appeal which guarantees a special brief process, established in the Law 62/1978 of Jurisdictional Protection of Fundamental Rights, 26 December 1978. The Spanish Constitutional Court (from now on, TC), in its decision 81/1992 of 28 March 1992, stated that: "la preferencia implica prioridad absoluta por parte de las normas que regulan la competencia funcional o despacho de los asuntos por sumariedad, como ha puesto de relieve la doctrina, no cabe acudir a su sentido técnico (pues los procesos de protección jurisdiccional no son sumarios, sino especiales), sino a su significación vulgar como equivalente a rapidez. Con lo que se entiende que simplemente se le da una prioridad destacada por encima del resto de casos a la hora de resolver el conflicto".

Secondly, Article 53.2 CE also recognizes an individual claim for the protection of the basic rights and freedoms before Constitutional Court (recurso de amparo). The competence of the Spanish Constitutional Court to judge fundamental rights violations is contained in Article $161.1 \mathrm{~b}$ ) of the Spanish Constitution. These appeals for protection are one of the most important functions of the Constitutional Court in order to protect the fundamental rights and freedoms included in articles 14 to 29, and 30.2 of the Spanish Constitution and they can only be used to reestablish or restore the rights and freedoms on which the appeals are based.

Thirdly, protection is also granted by means of the constitutional appeal (recurso de inconstitucionalidad) established in Article 161.1 a) of the Spanish Constitution. This appeal consists of a defense against laws and legal provisions which violate one of the fundamental rights contained in the Spanish Constitution, previously enumerated.

Fourthly, another way in which the Constitution protects the fundamental right to peaceful assembly is by requiring their regulation by Organic Acts, as established in Article 53.1, whose passing, amendment or repeal will require an absolute majority of the members of the Congress. This special consensus is considered to be another mean of protection of this fundamental right, as it is contained in Articles 81.1 and 81.2 of the Spanish Constitution. Moreover, this regulation should respect, in any case, its essential content, without any limitation or reduction from what it is exposed in the Constitution. Furthermore, there is also an explicit prohibition in Article 86.1 of the Spanish Constitution in using decree-laws (whose passing, amendment or repeal requirements are lower), when these affect the fundamental rights and liberties contained in Title One, even if it is a case of extraordinary and urgent need. 
Lastly, the modifications of the right to peaceful public assembly, as it is part of Title I, Chapter II, Section I, have to be done observing a special procedure which requires an approval of two-thirds majority of the members of the Congress and the Senate; a subsequent dissolving of the Cortes Generales; new legislative elections; the approval by a two-thirds majority of the new elected members of both Houses and its ratification by referendum.

\subsection{Constitutional Standards of Protection of the Right to Public Assembly.}

In this section we will focus on the research and analysis of the different standards of protection contained in the Spanish Constitution regarding the fundamental right to peaceful public assembly and demonstration: a. Legality; b. Necessity; c. Proportionality.

\section{a. Legality}

The principle of legality is a fundamental standard which indicates that the exercise of the public power must be done in accordance with an applicable law, valid at that precise moment in time. Furthermore, as established before, fundamental constitutional rights are under the principle of legal reservation and so, they have to be developed by an Organic Act. As a consequence, they cannot be developed by other means of regulation, as it has been stated by the Spanish Constitutional case-law": "estamos ante un dogma básico de todo sistema democrático".

Now, focusing on the process used to pass the modification of Public Safety Organic Act (from now on PSOA), it has been approved by the Government using the absolute majority it has, both in the Congreso de los Diputados and the Senate. A vast part of the opposition parties, in the belief that this is contrary to the majority requirements proclaimed by the Constitution submitted this law to a constitutional appeal ${ }^{2}$ (recurso de inconstitucionalidad). Such appeal was presented by more than 50 deputies from different parties (PSOE, Izquierda Plural, UPyD, Compromís-Equo, Coalición Canaria and Geroa Bai), regarding several articles of the Act. The Spanish Constitutional Court has not decided yet about their constitutionality, meaning that these articles and the whole PSOA are still applicable nowadays.

\footnotetext{
${ }^{1}$ Spanish Constitutional Court, 108/1986

${ }^{2}$ Recurso de inconstitucionalidad núm. 2896-2015
} 
Some of those articles which were considered to be unconstitutional by the opposition parties $(36.2,37.1,30.3$ and 37.3) had to do with restrictions to the right to peaceful public assembly and demonstration. Among other infractions, assemblies and demonstrations in front of the Congreso de los Diputados, the Senate or the Regional Legislative Assemblies are punished as a serious offence.

Article 30.3 of the new PSOA establishes who shall be considered as the promotor of a demonstration. It says that while not having signed or submitted the prior communication, whoever has led, directed or promoted such acts shall also be considered as an organizer. Moreover, those who participate in the demonstration by oral or written statements, disseminating slogans, or showing flags or other signs may be considered as directors too. With this regulation, almost every person who has been in a demonstration and has encouraged other people to join them or written about it, can be said to be the promotor. Moreover, whoever carries a placard with slogans or located at the forefront of a demonstration may also be considered as a promotor. Consequently, this article does not leave many people out of the consideration of "promotors". In addition, the Article 36.1 of the PSOA may violate the principle of legality because its relevant punishable conduct is wide indeterminate. ${ }^{3}$

\section{b. Necessity}

The principle of necessity establishes that every punishment has to be in compliance with general and special prevention requirements. It works from a double perspective: the abstract penal combination and the concrete imposition of the punishment. In the first one, it is related to the principle of minimum intervention; while in the second one, it has to do with the individual determination of the punishment, the enforcement and suspension of the punishment and the use of penal substitution.

In this case, and according to our criterion the punishments established by the PSOA for very serious offences (fines from $30.001 €$ to $600.000 €$ ), serious offences (fines from $601 €$ to $30.000 €$ ) and less serious offences (fines from $100 €$ to $600 €$ ) are completely out of proportion

\footnotetext{
${ }^{3}$ Portilla Contreras, G. "Derecho de manifestación y desórdenes públicos", en Protección jurídica del orden público, la paz pública y la seguridad ciudadana, dir. María Luisa Cuerda Arnau y Juan Antonio García Amado. Tirant lo Blanch, Valencia 2013, 74 .
} 
considering its purpose and, in fact, they do not comply with the principle of minimum intervention. For instance, demonstrating without the administrative authorizations is considered as a very serious offence and so, people demonstrating can be punished with a fine from $30.001 €$ to $600.000 €$, which cannot be afforded by most part of the Spanish citizens. Another example is the punishment regarding the non-cooperation with the security forces in crimes inquiries or in prevention of actions which can put at risk the public security, as it is considered as well as a serious offence. This fine is against the Constitutional Right to not to testify against oneself, recognized in article $24.2 \mathrm{CE}$. This standard of protection is closely related to the principle of proportionality, which will be analyzed below.

\section{c. Proportionality}

The principle of proportionality tries to avoid an excessive use of punishments which entail a loss or a restriction of freedom. These kinds of punishments should be imposed only to protect the most valuable legally protected goods. Furthermore, in order to enforce a punishment properly, it has to be proportionate to the objective pursued. The optimal punishment should be qualitatively and quantitatively appropriate to the purpose.

It should be said that Criminal Law has a subsidiary nature. It should not regulate all the public and private life areas and it should be ruled by the principle of minimum intervention. As a consequence, it should be used just in extraordinary serious situations (carácter fragmentario) and in case other, less restrictive, mechanisms of protection have failed (naturaleza subsidiaria). Nevertheless, during the last years the different governments have followed legislative proliferation policies that restrict people's freedom with disproportionate punishments and measures.

Furthermore, the principle of proportionality also affects another area of the right to demonstration: Police intervention in situations of serious disruptions during a demonstration. The intervention of the Police Forces in a demonstration which is in no compliance with the Law has to be ruled by the principle of proportionality. This means that if the demonstration is pacific but it has not been previously communicated (notified), the participants can be requested to put an end to it, but they cannot be object of a violent evacuation which implies a disproportionate use of force. As the Spanish Supreme Court ${ }^{4}$ has established in several

\footnotetext{
${ }^{4}$ Supreme Court Case Law of de 30 de abril de 1987, 6 de febrero de 1991, 16 de octubre de 1991
} 
occasions, the participants' behavior, their way of reacting, and their continuity in that situation should be taken into account.

\subsection{Definition of the right to peaceful public assembly}

On the one hand, one of the main problems that we have to take into consideration when analyzing the right to peaceful public assembly is the lack of definition in the Spanish Constitution. This legal concept has been constructed by both Constitutional and Supreme courts and jurists. Pérez Serrano considers that the right to peaceful public assembly should be defined as "la facultad de congregarse con otras personas transitoriamente, fuera del domicilio habitual y para un fin común, que debe ser de carácter público",5. In this definition, we can find different components: the plurality of parties, a specific place and moment and the aim of the action.

On the other hand, the Spanish Constitutional Court, in its ruling 66/1995, May 8, goes further and gives a more complete definition: "el derecho de reunión, según ha reiterado este Tribunal, es una manifestación colectiva de la libertad de expresión ejercitada a través de una asociación transitoria de personas, que opera a modo de técnica instrumental puesta al servicio del intercambio o exposición de ideas, la defensa de intereses o la publicidad de problemas y reivindicaciones, y cuyos elementos configuradores son el subjetivo -agrupación de personas - el temporal — duración transitoria - el finalista — licitud de la finalidad - y el real y objetivo -lugar de celebración”. The Court connects its previous definitions regarding the right to peaceful public assembly with the right to freedom of expression. Moreover, it states that the right to peaceful public assembly is an individual right which is exercised collectively by the plurality of people, as mentioned in both definitions.

The Spanish Supreme Court has established a definition of the right to peaceful public assembly in diverse rulings too. In its ruling 163/1991, June 26, it affirms that "el derecho de reunión aparece concretado por la concurrencia concretada y temporal de más de 20 personas con finalidad determinada, concurrencia que no necesita comunicación previa pero cuyo ejercicio queda sometido al régimen de comunicación previa en los casos de reuniones en lugares de tránsito público y manifestaciones...". In this definition, the Court states as a formal requisite the temporal concurrence of more than 20 people. Moreover, it emphasizes that the

\footnotetext{
${ }^{5}$ Perez Serrano, N. Tratado de Derecho Político, Madrid, 1976, p.665.
} 
right to peaceful public assembly is under the communication system, which is one of its limits, and this right must be exercised in an atmosphere of peace and public order. By the term public order, the Court understands the regular development of acts under the Rule of Law. Therefore, authorities are able to interfere in the exercise of this right when they have well founded indicators that a public disorder will take place in the area where the demonstration will be held. As it is shown, both the Spanish Constitutional Court and Supreme Court, in different rulings, have established a definition of the right to assembly, each of them with its own nuances.

\subsection{Spanish Constitucional Court Case-Law}

The Spanish Constitutional Court, in its ruling 96/2010, November 5th, declared that in order to ban a demonstration, there should be founded reasons that the exercise of the right to peaceful public assembly will affect public order or other rights and goods protected by the Spanish Constitution: "para que los poderes públicos puedan incidir en el derecho de reunión, restringiéndolo, modificando las circunstancias de su ejercicio, o prohibiéndolo, es preciso que existan razones fundadas, lo que implica una exigencia de motivación de la resolución correspondiente en la que se aporten las razones que han llevado a la autoridad gubernativa a concluir que el ejercicio del derecho fundamental de reunión producirá una alteración del orden público o la desproporcionada perturbación de otros bienes o derechos protegidos por nuestra Constitución. Pero para ello no basta con que existan dudas sobre si el derecho de reunión pudiera producir efectos negativos, debiendo presidir toda actuación limitativa del mismo el principio o criterio de favorecimiento del derecho de reunión...”. Furthermore, a resolution which bans a demonstration must be a reasoned decision. Those requisites are established in Article 21.2 of the Spanish Constitution. The principle pro libertate must also be taken into consideration when there are attempts of limitation which are unjustified or have a limited justification, as it is established in the following Spanish Constitutional Court rulings: 36/1982, $163 / 2006$ and $170 / 2008$.

One of the requisites to prohibit a demonstration is the concurrence of public disturbance altering the public order. The Spanish Constitutional Court ruling 66/1995, May 8th, specified when a situation may be considered as public disorder and established that these situations take place when the normal development of life is impeded by affecting people's physical and moral integrity or public and private goods' integrity: "situación de desorden 
material en el lugar de tránsito público afectado, entendiendo por tal desorden material el que impide el normal desarrollo de la convivencia ciudadana en aspectos que afectan a la integridad física o moral de personas o a la integridad de bienes públicos o privados. Estos son los dos elementos que configuran el concepto de orden público con peligro para personas y bienes consagrado en este precepto constitucional. Ciertamente, el normal funcionamiento de la vida colectiva, las pautas que ordenan el habitual discurrir de la convivencia social, puede verse alterado por múltiples factores, que a su vez pueden afectar a cuestiones o bienes tan diversos como la tranquilidad, la paz, la seguridad de los ciudadanos, el ejercicio de sus derechos o el normal funcionamiento de los servicios esenciales para el desarrollo de la vida ciudadana; sin embargo, sólo podrá entenderse afectado el orden público al que se refiere el mentado precepto constitucional cuando el desorden externo en la calle ponga en peligro la integridad de personas o de bienes... no cualquier corte de tráfico o invasión de calzadas producido en el curso de una manifestación o de una concentración puede incluirse en los límites del artículo 21.2 CE”. As a consequence, not every invasion or cut of roads during a demonstration can be included in the exceptions of Article 21.2 of the Spanish Constitution.

From this ruling it is possible to infer that a demonstration can only be banned in application of article 21.2 of the Spanish Constitution when the disorder in the street places people or goods in danger. In many occasions, police forces have used the street invasion (affecting either vehicle or people transits), as a way to intervene and put to an end a demonstration. This judgment clearly states that the interruption of traffic and the restriction of citizenship freedom of movement are circumstances which cannot be excluded from the right to assembly (settled case-law by the Decision 195/2003, October 27 of the Constitutional Court). This legal principle forces to the limit the administrative prohibition to exceptional cases in which whether the interruption of traffic or public mobility (freedom of movement) have been used as an excuse to avoid the authorization of public demonstrations. In case of doubt, the most favorable criteria should be applied (as stated before, principle pro libertatis).

Finally, the preservation of public order cannot be an argument to forbid a demonstration which proclaims ideas that may contradict the formal public order (neutral content protection). This standard of protection is expressed in the Spanish Constitutional Court ruling 301/2006, October 23, when the Court states that: "el contenido de las ideas sobre las reivindicaciones que pretenden expresarse y defenderse mediante el ejercicio de este derecho no puede ser sometido a controles de oportunidad politica". 


\subsection{Article 513 and 557, Criminal Code}

On the one hand, the Criminal Code in its article 513 considers as unlawful assemblies or demonstrations those deemed to be held in order to commit a crime or those attended by persons carrying weapons, explosive devices or any other dangerous items. ${ }^{6}$ Due to its vagueness, it is useful to look into the case-law in order to obtain a definition of what should be considered as a dangerous item: "The Code does not specify on the weapons or dangerous objects, neither the number of carriers participating in the meeting. We understand that it has to be a substantial, significant number and a considerable amount of people carrying dangerous objects, which could give and external appearance of violence."7

On the other hand, the modification of the Criminal Code performed in 2015 eroded the content of article 557 which regulates the Public Disorder Offence. On its previous wording, this article established prison time from six months up to three years for those who acting as a group and in order to disturb the public peace, alter public order causing injury to persons, damaging property, blocking the public thoroughfares or access to these in a way that endangers those travelling along them, or trespassing on premises or buildings. Instead, its new configuration not only loses the requirement of performing these behaviors in order to disturb the public order, but also they may be punished when performed in group or individually but covered by a group. Moreover, the sole action of threatening people with violent performances upon people or goods will also be considered as a felony sanctioned by this article. As seen, this wording is open wide and it enables the punishment of behaviors not completely described as accurate as a Criminal Code should be. ${ }^{8}$

\subsection{Private Security Services Act}

Private security has experienced a significant increase during the last years due, not only, to the intensification of a social insecurity atmosphere, but also to the impossibility for security forces to cover and reach every sector. Moreover, the previous regulation of private security was outdated, as it was enacted in 1992 (Private Security Services Act 23/1992).

\footnotetext{
${ }^{6}$ Portilla Contreras, G. "Derecho de manifestación y desórdenes públicos”... 77.

${ }^{7}$ SAP de Zaragoza, 3a, 17-11-2003 (JUR/2004/5125)

${ }^{8}$ Quintero Olivares, G. "Derecho de manifestación y desórdenes públicos", en Protección jurídica del orden público, la paz pública y la seguridad ciudadana, dir. María Luisa Cuerda Arnau y Juan Antonio García Amado. Tirant lo Blanch, Valencia 2013, 156-158.
} 
It is in this context when the Spanish Ministry of Intern Affairs presented the new Private Security Services Act, as a regulation which covers the entire number of subjects that give form to that sector and which offers legal definitions for previous Law vague or inexistent concepts. Therefore, its justification is based on the shortages of the previous Law which were attempted to be corrected with a regulation, but had not been relieved considering the increasing development of private security sector. This new wording is considered to be necessary in order to improve private security services and the formation and juridical backup of private security staff; as well as to establish a greater collaboration between private and public forces.

The Private Security Services Act 5/2014 has to be analyzed under an essential statement: the guarantee of public safety is a function which has to be exclusively guaranteed by public forces. The State is the only one in charge of guaranteeing such functions, therefore, they cannot be delegated to private companies, because they are functions that involve the exercise of public authority in protection, for instance, of fundamental rights and liberties. Moreover, public safety must be enforced by public security forces, who are the main guarantors of the rights of citizens and the Rule of Law, being this their main task. In relation to our report, articles 31, 32 and 41 may clash with fundamental rights as in the stated situations, according to our vision, proportionality is distorted.

\section{a. Article 31: The consideration as public authority of private service personnel.}

The consideration of authority that the Law stated for private services personnel has been one of the most relevant requests done by this sector and was contained in the draft of the bill. Nevertheless, after many critiques, the draft was amended and it came to establish that private security staff will only be considered as a public authority in case of aggressions and disobediences against them when they carry out activities of their competences in collaboration with public security forces (Article 31$)^{9}$. To this aim, it is possible to find diverse rulings from the European Court of Justice ${ }^{10}$, which establish that private security companies are not directly part of public power, due to the fact that a contribution to reach public safety cannot imply the

\footnotetext{
${ }^{9}$ Portilla Contreras, G. "Derecho de manifestación y desórdenes públicos", ...66.

${ }^{10}$ European Court of Justice, Comission/Belgium, October 29, 1998 (C-114/97). European Court of Justice, Comission/Italy, May 31, 2001 (C-238/99).
} 
exercise of a public power. The Spanish Supreme Court ${ }^{11}$ also denies the role of security guards as authority agents. As public authorities' assistants, they have the consideration of civil servants just when they perform their functions in cooperation and under the commands of the authority forces. The consideration or not as authority agents is important ${ }^{12}$ in relation to the legitimate use of force, which can restrict citizens' fundamental rights such as personal freedom, physical and moral integrity, secrecy of communications, inviolability of the home, honor, intimacy and own image.

\section{b. Performing their task in public demonstrations}

The new Private Security Services Act extends the private action to areas previously reserved to public forces only. As a consequence, it must be pointed out that this situation may affect in a negative way to the protection of the rights of citizens as private services personnel do not receive the same formation as police forces do regarding constitutional rights, and Law in general.

From our point of view, and in reference to the analysis of the right to peaceful public assembly and demonstration, it is the right to personal freedom the one which is seriously affected by this new regulation. The right to personal freedom is recognized in Article 17 of the Spanish Constitution and also protects personal security. It is a fundamental right which is protected by all mechanisms and guarantees provided by the legal system. Moreover, citizens cannot be deprived of this freedom out of the legally established situations.

Related to this fundamental right, detention is a precautionary measure which involves temporary deprivation of a person's freedom in order to clarify specific facts. This function can be carried out by public security forces and, in some occasions, by private individuals that for instance are witnesses of a crime. Moreover, the Private Security Services Act 5/2014, introduces a new way to preclude this right, private security personnel, when performing their duties all together with public forces, are entitled to conduct detentions. Once again, we may rise the question of what kind of formation these people receive; and if this extension may be considered as a direct overflow of the public powers that must be exercised only by public forces, as this implies the limitation of constitutionals rights.

\footnotetext{
${ }^{11}$ Spanish Supreme Court, Criminal Section, 718/2013, October.

${ }^{12}$ Ridaura MArtínez, J. "Seguridad Privada y Derechos Fundamentales. La nueva Ley 5/2014, de 4 de abril, de Seguridad Privada”, Tirant Monografías 970, 2015.
} 


\section{c. Prevention of crime}

This new Act establishes that private security agents have the obligation to prevent the commission of criminal acts or administrative infractions and so, they have to carry out the necessary verifications to prevent or impede them. Therefore, security guards are empowered to perform the detention of those people trying to commit or having committed a criminal act and taking them before the public forces. In relation to that detention, private security agents are not obliged to inform people under arrest about their rights, as their unique obligation is to perform the detention and bring arrested people before the public forces.

\section{d. Migrant Detention Centers}

The Private Security Services Act gives the opportunity to private security agents to work in prisons or detention centers for migrants (Centro de Internamiento de Extranjeros [CIE]) in its Article $41.3 \mathrm{a}$ ) and b), by widening their faculty of detention in case of escape. In addition to that, private security agents are considered to be authority agents in both centers, as they are acting under the control and supervision of public forces and they are allowed to carry firearms if it is necessary to guard those centers.

For all these reasons, we consider that this new regulation implies a disproportionate actuation of private security services, as it allows them to effectuate detentions without the necessary guarantees. Fundamental rights such as personal freedom must be thoroughly protected. for this reason, a detention should not be carried out by private companies. It is contradictory that the new regulation broadens the scope of actuation of private security staff, up to the point of allowing them to carry out arrests, even in public spaces. The act not only is allowing them to carry out disproportionate detentions, but it also poses a problem when it comes to inform arrestees about their rights. The obligation to inform them about why they are under arrest is just for public officers, so that, detainees will not receive this information until they are handed over to public officers. 


\subsection{Public Safety Organic Act 4/2015}

The Public Safety Organic Act 4/2015 is the latest piece of legislation regarding the topic of this paper we are going to research into. For the most part, this Act regulates the action of police officers, the ways in which they can act, the new fines they can impose, the new rules regarding public safety and some small developments regarding public demonstrations and meetings.

Article 23 (Meetings and demonstrations) establishes the obligation of public authorities to take the necessary measures to protect the celebration of demonstrations and meetings, trying to avoid disturbances of public safety. Moreover, it settles that the intervention measures for the maintenance or restoration of public safety must be gradual and proportionate to the circumstances, considering the dissolution of demonstration as the last resort. It also instructs the security forces on how to proceed when taking those intervention measures. Before adopting any of those measures, public forces must inform the people affected about the measures that will be taken against them; which can be done orally in urgent situations. Nevertheless, in case of a grave disturbances of public safety with weapons, explosives or other dangerous artefacts, they are empowered to dissolve a meeting or a demonstration without any previous notification.

The most important thing about this article is that it establishes that public authorities may dissolve concentrations when these affect the transit of vehicles on public roads. This article entitles public officials to remove people or any other kind of obstacles when they impede, endanger or hinder the movement along these roads. Preciado says "[It] means, in practice carte blanche to dissolve as always, to a greater or lesser extent they hinder the flow along these routes"13, since it is clear that a demonstration or meeting in a place of public transit brings a degree of disorder in the development of everyday life and some discomfort, such as road closures and street cuts.

\footnotetext{
13 Preciado Doménech, C. H, “Anteproyecto de ley de represión ciudadana: un análisis jurídico”, 8 de diciembre de 2013. Disponible en: http://www.sinpermiso.info/textos/el-anteproyecto-de-ley-de-represin-ciudadana-un-anlisis-jurdico (acceso: 18 de abril de 2016).
} 


\section{Sanctions}

The sanctioning system is established in Chapter V of this Act. First of all, the chapter establishes who can be considered as responsible subjects and then it goes on to structure the severity of the different infringements.

Article 30.3 establishes the responsible subjects of the sanctions. We will divide the paragraph in two parts as the first part establishes the subjects specifically, and the second part is noted for its obscurity or vagueness. The first part considers the organizers or promoters of public meetings or public demonstrations the natural or legal persons who have previously submitted the required previous communication. The second part says, as we have already mentioned, that while not having signed or submitted the prior communication, whoever has led, directed or promoted such acts shall also be considered as an organizer. Moreover, those who participate in the demonstration by oral or written statements, disseminating slogans, or showing flags or other signs may be considered as directors too.

But the worst part of this sanctioning system is the grievous fine scheme established by this Act, as mentioned before. The first degree refers to very serious offences which are fined from 30.001 to 600.000 Euros. Serious offences stand for the second degree and are fined from 601 to 30.000 Euros. Lastly, less serious offences are fined from 100 to 600 Euros. The Act renders as a very serious offence unreported or prohibited demonstrations or meeting nearby facilities that provide basic services to the community. Instead, serious offences are broader, including "the disturbance of public safety" of meeting or demonstrations in front of the Spanish Parliament (both chambers) and regional legislative bodies, as well as "causing disorder" in public roads, or disobeying the public authorities in the exercise of their functions. Although, it needs to be said that this same article establishes some protection for the legally organized demonstrations as it treats the disturbance of the as a serious offence.

\subsection{Peaceful Public Assembly Regulatory Act}

Requirements to peaceful public demonstration.

Meetings in public places and demonstrations shall be communicated in writing to the appropriate governmental authority by the organizers or promoters of those, with an advance of 
ten calendar days. For the case of legal persons, the communication should be done by its representative. When there are extraordinary and serious reasons which justify the urgency of calling and holding of meetings in public places or events, communication, referred to above, may be made with a minimum of twenty-four hours.

The writing to the public authorities shall include:

- Name, address and official identification of the organizer or organizers or their representative, for legal entities, also stating the name, nature and address of them.

- Place, date, time and expected duration.

- Object of the demonstration.

- Planned itinerary, when it is going to take place on public roads.

- Security measures provided by the organizers or requested by the governing authority.

The governmental authority notifies the City Council the data contained in the written form, except in the case of an urgent call, so that the Council reports an answer within twentyfour hours on the circumstances of the proposed route. If the report is not received within that period, it shall be deemed favorable. The report shall refer to objective reasons such as the state of the places intended proposed, overlapping with other acts, the security of the places under the rules and regulations and other of technical nature. In any case, the report is not binding and must be motivated. 


\section{International standards of protection of the right of peaceful assembly}

In order to establish whether the Spanish Public Safety Organic Act violates Human Rights, we shall identify the international standards of protection of the right to peaceful public assembly. First of all, the Universal Declaration of Human Rights in its article 20.1 establishes that "Everyone has the right to freedom of peaceful assembly and association". However, it is not a treaty, so therefore it is not legally binding for countries. In despite of this, it is a clear expression of the fundamental values shared by the members of the international community, and it has served as an inspiration for the development of posterior covenants and for International Human Rights Law.

The right to peaceful public assembly is a right of all, therefore as a general rule it cannot be limited. However, in certain occasions such right can be restricted for national security or public safety reasons, to guarantee the public order or to protect the rights and freedom of other. In any case, this shall be done in accordance to International Law, avoiding the violation of human rights -principle of legality-.

Moreover, States have the positive obligation of protecting and facilitating the enjoyment of the right to peaceful public assembly. This means that the measures taken which restrict such right, such as the use of force, must be done uniquely when necessary -principle of necessity-, and in proportionality with the situation - principle of proportionality-.

The right to freedom of peaceful assembly derives mainly from three international legal instruments. Firstly, we shall make reference to some resolutions from the Human Rights Council (inter-governmental body within the United Nations system); secondly, we will focus on the International Covenant on Civil and Political Rights (ICCPR) and its interpretation by the Human Rights Committee. Finally, we will analyze the European Convention for the Protection of Humans Rights and Fundamental Freedoms (ECHR) and the interpretation offered by the case-law of the European Court of Human Rights regarding such right. 


\subsection{The Human Rights Council}

The Human Rights Council is an intergovernmental body within the United Nations system in charge of making sure that Human Rights are guaranteed and protected all around the world and one of their tasks is to formulate recommendations to Member States. The Council was created by the UN General Assembly in 2006 and is composed of 47 United Nations Member States. For this reason, we consider it is important to mention Resolution 15/21 ${ }^{14}$, adopted by the Human Rights Council regarding the rights to freedom of peaceful assembly and association. This Resolution, together with Resolutions 21/16 ${ }^{15}$ (October 2012) and 24/5 (October 2013), emphasizes that we all have the right to freedom of peaceful assembly and association, and such rights can be subject only to the restrictions permitted in accordance to International Law, especially International Human Rights Law. Moreover, States must fully respect and protect the rights of all individuals to assemble peacefully and associate freely, meaning that they have the positive obligation of taking all the necessary measures in order to guarantee the exercise of the rights to freedom of peaceful assembly and association, without exceeding the rights established by the Law.

Secondly, it is important to highlight the task of the United Nations High Commissioner for Human Rights. Whilst the Human Rights Council is a subsidiary body of the General Assembly, the High Commissioner for Human Rights is a completely different entity from the Council, and it supports its work and collaborates with governments and civil societies with the aim of ensuring that international standards of Human Rights are applied around the world and promotes International Law and Human Rights education. The Special Rapporteur on the rights to freedom of peaceful assembly and association Maina Kiai, recommended in $2012^{17}$ all States to protect and facilitate peaceful assemblies without the use of Law enforcement authorities. Them should be used only when force is completely necessary. Furthermore, Kiai highlighted the fact that the exercise of such right cannot be subject to prior authorization from the authorities, however States may request prior notification.

\footnotetext{
14 See UN Doc. A/HRC/RES/15/21, 6 October 2010, accessible at: \begin{tabular}{l} 
http://www.icnl.org/research/resources/dcs/UNHRCResolution.pdf (visited the 20th January 2016). \\
\hline See UN $\quad$ Doc. A(HRC/RES/21/16, $11 \quad$ October 2012, accessible at:
\end{tabular} http://ap.ohchr.org/documents/dpage e.aspx?si=A/HRC/RES/21/16 (visited the 9th May 2016)

${ }^{16}$ See UN Doc. A/HRC/RES/24/5, 8 October 2013: http://ap.ohchr.org/documents/dpage e.aspx?si=A/HRC/RES/24/5 (visited the 9th of May 2013)

${ }_{17}$ See UN Doc. A/HRC/20/27, Report of the Special Rapporteur on the rights to freedom of peaceful assembly and of association, Maina Kai, $21 \quad$ May 2012, accessible at: http://www.ohchr.org/Documents/HRBodies/HRCouncil/RegularSession/Session20/A-HRC-20-27 en.pdf (visited the 20th January 2016).
} 


\subsection{The International Covenant on Civil and Political Rights}

The International Covenant on Civil and Political Rights (here in after ICCPR), together with the Universal Declaration of Human Rights and the International Covenant on Economic Social and Cultural Rights conform the International Bill of Human Rights. The ICCPR was adopted by the General Assembly of the United Nations on the 16th of December of 1966, and sets out the minimum standards in the area of civil and political rights. By virtue of its ratification, countries are obliged to preserve and protect the basic Human Rights established in it, and in this way governments shall take legislative, administrative and judicial measures in order to guarantee such rights and provide an effective remedy.

In its article 21 it establishes the right to peaceful assembly:

The right of peaceful assembly shall be recognized. No restrictions may be placed on the exercise of this right other than those imposed in conformity with the law and which are necessary in a democratic society in the interests of national security or public safety, public order (order public), the protection of public health or morals or the protection of the rights and freedoms of others.

\subsubsection{Human Rights Committee reports, regarding article 21 .}

In order to understand the meaning of the articles established in the ICCPR, the Human Rights Committee has adopted a series of General Comments. However, it has not yet adopted a General Comment regarding the right to peaceful assembly. In despite of this, the General Comment No. 31 expresses the obligations of the State Parties which have ratified the Covenant. In fact, paragraph 3 of the General Comment No. 31 states that State Parties shall respect the rights included within the Covenant and all branches of the government, including the public authorities shall "ensure them to all individuals in their territory and subject to their jurisdiction" $" 18$.

\footnotetext{
18 See UN Doc. CCPR/C/21/Rev.1/Add. 13, General Comment No. 31 of the Human Rights Committee, 26 May 2004 , accessible http://tbinternet.ohchr.org/ layouts/treatybodyexternal/Download.aspx?symbolno=CCPR $\% 2 \mathrm{fC} \% 2 \mathrm{f} 21 \% 2 \mathrm{fRev} .1 \% 2 \mathrm{fAdd} .13 \& \mathrm{La}$ $\underline{\mathrm{ng}=\mathrm{en}}$ (visited the 20th January 2016).
} 
Moreover, the General Comment establishes in its paragraph 6 that State Parties have both the positive and negative legal obligation of ensuring the rights included within the Covenant and they must refrain from violating such Human Rights. This implies that the restrictions upon any of these rights must be: 1) permissible under the Covenant itself; 2) necessary in order to achieve the legitimate objectives; 3) proportional to the achievement of such objectives for the protection of the rights included within the Covenant and finally, under no circumstances "may the restrictions be applied or invoked in a manner that would impair the essence of a Covenant right".

It is worth to stress that the Human Rights Committee elaborates concluding observations or concluding comments which are assessments of how States implement Human Rights treaties. According to this, the Committee, after having examined the sixth report submitted by Spain (CCPR/C/ESP/6), has expressed in the concluding observations its concerns regarding the restrictions imposed upon the freedoms of expression, associations and peaceful assembly as a consequence of the adoption of the Public Safety Organic Act in 2015. This Act has been strongly criticized by various sectors of society, and in fact the Committee is especially worried about the introduction of new administrative sanctions within the Law limiting some essential judicial guarantees, particularly the use of "vague and ambiguous terminology which may lead to a broad margin of discretion in the implementation of such legislation" 19 and the prohibition of making use of images, personal or professional data of authorities or State security forces. For this reason, the Committee formulates a series of recommendations for the Spanish government, and in regards to this matter it evokes the positive obligation of the States of guaranteeing the full enjoyment of the rights to freedom of expression, association, and peaceful assembly, which are rights of all individuals. Moreover, it points out the negative obligation of States of making sure that the restrictions to these rights fulfill the requirements established within the International Covenant on Civil and Political Rights, without placing unnecessary obstacles in the way of individuals wishing to protests.

On such basis, the Human Rights Committee believes that the Spanish State must revise the PSOA and also the implemented reforms of the Spanish Penal Code, with the aim of fully assuring the rights and liberties established within the Covenant.

\footnotetext{
${ }^{19}$ See UN Doc. Concluding Observations of the Human Rights Committee regarding the sixth periodic report of Spain, paragraph 25, translated by Olga Lenzi. Accessible in Spanish at: http://www.refworld.org/pdfid/5645936a4.pdf (visited the 20th January 2016). This idea has also been highlighted in Presno Linera, M. Á., "La expansión del derecho administrativo sancionador securitario: análisis constitucional de la Ley Orgánica para la protección de la seguridad ciudadana", en: Protección jurídica del orden público, la paz pública y la seguridad ciudadana, dir. María Luisa Cuerda Arnau y Juan Antonio García Amado. Tirant lo Blanch, Valencia 2013, 44-49.
} 


\title{
3.3. European Convention on Human Rights (ECHR)
}

Further on we shall make a brief analysis of article 11 of the European Convention on Human Rights, treaty signed in 1950 by 12 Member States of the Council of Europe, now having 47 signatory States. We will focus on the interpretation of the case-law offered by the European Court of Human Rights (here in after ECtHR), and finally we shall stand out the standards of protection.

\subsubsection{Article 11}

\begin{abstract}
Article 11 - Freedom of assembly and association
1. Everyone has the right to freedom of peaceful assembly and to freedom of association with others, including the right to form and to join trade unions for the protection of his interests.

2. No restrictions shall be placed on the exercise of these rights other than such as are prescribed by law and are necessary in a democratic society in the interests of national security or public safety, for the prevention of disorder or crime, for the protection of health or morals or for the protection of the rights and freedoms of others. This Article shall not prevent the imposition of lawful restrictions on the exercise of these rights by members of the armed forces, of the police or of the administration of the State
\end{abstract}

Article 11 recognizes two fundamental rights: 1) the right to freedom of peaceful assembly and 2) the right to freedom of association. These two rights are closely related as the right to assemble would be less effective if one cannot associate freely. In fact, as stated within the article, the Convention explicitly protects peaceful assemblies, which means that violent demonstrations with the aim of causing public disorder are not protected under such article. Therefore, any assembly organized, since the beginning, with the intention of violence does not fall within the scope of application of article 11 of the European Convention. However, "even where the intentions of demonstrators are not violent public demonstrations may nevertheless pose a threat to public order when counter-demonstrators also assert their right to freedom of peaceful assembly. In such circumstances, the Court has held that the State has the positive obligation to protect those exercising their right to freedom of peaceful assembly from the threat of counter-demonstrations."20

\footnotetext{
${ }^{20}$ INTERIGHTS, "Freedom of Peaceful Assembly and Association under the European Convention on Human Rights (Article 11)", London 2011, pg. 10.
} 
As a general rule, the right to freedom of peaceful assembly shall be enjoyed without regulation. This means that any action not prohibited by the Law, is presumed permissible and therefore legal. In fact, as stated by article 1 of the Convention, The High Contracting Parties shall secure to everyone within their jurisdiction the rights and freedoms defined in Section I of this Convention, which clearly represents the State responsibility. In fact, States have both positive and negative obligations. The former refers to the obligation of States of ensuring the respect for the rights guaranteed under article 11. The later instead refers to the abstention of States from interfering with the right to peaceful assembly, unless this interference is due to any of the exceptions established in article 11.2. This article establishes that the restriction of the right to peaceful assembly must be "necessary in a democratic society in the interests of national security or public safety, for the prevention of disorder or crime, for the protection of health or morals or for the protection of the rights and freedoms of others". Therefore, in case the interference in the such right cannot be justified in any of these legitimate aims, there will be a violation of Article 11.

Once the Court considers that the restriction is based in any of the aforementioned aims, the next step is to analyze whether it fulfills with the proportionality test. Regarding this principle, for an action to be proportional to the aim or aims pursued, "the national authorities are required to use the method that least restricts the right protected in Article 11. In order to decide whether the authorities have succeeded in doing so, it must be examined whether a proper balance has been achieved between the conflicting interest of those involved." ${ }^{21}$ Later on, we shall analyze the principle of proportionality in depth, and some examples from the European Court of Human Rights regarding proportional and non-proportional measures restricting the right to peaceful assembly adopted by States will be given.

Finally, article 11 in fine establishes that States are entitled to lawfully restrict the right to peaceful assembly and association of members of the armed forces, members of the police or the members of the administration of the State.

\footnotetext{
${ }^{21}$ INTERIGHTS, "Freedom of Peaceful Assembly and Association under the European Convention on Human Rights (Article 11)", London 2011, pg. 41.
} 


\subsection{Interpretation of article 11 by the European Court of Human Rights}

The ECtHR since its creation, has delivered more than 10,000 judgments, which "are binding on the countries concerned and have led government to alter their legislation and administrative practice in a wide range of areas. The Court's case-law makes the Convention a powerful living instrument for meeting new challenges and consolidating the Rule of Law and democracy in Europe." 22 In fact, the European Court of Human Rights has produced a rich body of case-law on the right to peaceful assembly. Therefore, with the aim of understanding its interpretation of article 11 of the Convention, we shall focus on some leading cases.

First of all, it must be clear that the right to peaceful assembly is considered a fundamental right within a democratic society, being one of its foundations. ${ }^{23}$ Meaning that States have the positive obligation of safeguarding the exercise of such right, and must "refrain from applying unreasonable indirect restrictions upon that right"24; which means that States must not apply, with no legal basis, restrictions on other fundamental rights which consequently result in the limitation of the right to peaceful assembly, unless there is a compelling justification for doing so, such as, for example, indirect restrictions on the right to liberty and freedom of movement (Article 12 of the ECHR and Article 2 of Protocol 4 of the ECHR). ${ }^{25}$

Moreover, when we speak about the right to peaceful assembly it is important to clarify which are the types of assemblies protected by the European Convention. As established by the jurisprudence, this right covers both private and public meetings ${ }^{26}$, and "not only static meetings, but also public processions. ${ }^{, 27}$ Even though article 11 covers any meeting, either for economic or political reasons, "it is unlikely to be applicable to gatherings that are purely social or are sporting in character. ${ }^{28}$ However, it is worth noting that Article 11, as a general rule, will

\footnotetext{
22 Council "Migration and Human Rights", http://www.coe.int/t/democracy/migration/bodies/echr en.asp (visited the 3rd March of 2016).

${ }^{23}$ European Court of Human Rights (First Section), Case Primov and others v. Russia, (Application no. 17391/06), 12 June 2014, para. 116.

${ }^{24}$ European Court of Human Rights (First Section), Case Adali v Turkey, (Application no. 38187/97), 31 March 2005, para. 267.

25 OSCE/ODIHR.: Guidelines on Freedom of Peaceful Assembly, Poland 2010 , p.60. Accessible at: http://www.osce.org/odihr/73405?download=true (visited the 6th May 2016)

${ }^{26}$ European Commission, application No. 8191/78, Rassemblement Jurassien and Unité Jurassienne v. Switzerland, Decision of 10 October 1979.

${ }^{27}$ European Commission, application No. 8440/78, Christians against Racism and Fascism v. United Kingdom, Decision of 16 Julio 1980, pg. 148.

28 INTERIGHTS, "Freedom of Peaceful Assembly and Association under the European Convention on Human Rights (Article 11)", London 2011, pg.8.
} 
not cover the right to hold a meeting in a privately owned public place without the owners' consent. $^{29}$

Regarding the beneficiaries from this right, it can be exercised by individuals, the organizers of the assembly and also associations. ${ }^{30}$ In fact, "the right to peaceful assembly is secured to everyone who has the intention of organizing a peaceful demonstration." 31 The word peaceful must be highlighted as it clearly conveys that either public or private meetings, organized with violent aims will not be covered by article 11 . What really matters is the intention, the intention of holding a peaceful assembly. However, as stated within Christians against Racism and Fascism vs. United Kingdom (1980):

\begin{abstract}
"The possibility of violent counterdemonstrations, or the possibility of extremists with violent intentions, not members of the organizing association, joining the demonstration cannot as such take away that right. Even if there is a real risk of a public procession resulting in disorder by developments outside the control of those organizing it, such procession does not for this reason alone fall outside the scope of Article II (1) of the Convention, but any restriction places on such an assembly must be in conformity with the terms of paragraph 2 of that provision., 32
\end{abstract}

Occasionally, peaceful demonstrations may pose a threat to public order when counterdemonstrators also claim their right to peaceful assembly. These situations, as stated within Plattform 'Artzefür das Leben' v. Austria (1988), require a positive obligation from the State:

\begin{abstract}
"A demonstration may annoy or give offence to persons opposed to the ideas or claims that it is seeking to promote. The participants must, however, be able to hold the demonstration without having to fear that they will be subjected to physical violence by their opponents; such a fear would be liable to deter associations or other groups supporting common ideas or interests from openly expressing their opinions on highly controversial issues affecting the community. In a democracy the right to counter-demonstrate cannot extend to inhibiting the exercise of the right to demonstrate. Genuine, effective freedom of peaceful assembly cannot, therefore, be reduced to a mere duty on the part of the State not to interfere: a purely negative conception would not be compatible with the object and purpose of Article 11. Like Article 8,
\end{abstract}

\footnotetext{
${ }^{29}$ European Court of Human Rights (Fourth Section), Case Appleby and Others v. The United Kingdom, (Application no. 44306/98), 6 May 2003.

${ }^{30}$ European Court of Human Rights. For individuals and organizers see Rassemblement Jurissien and UnitéJ urassienne v. Switzerland (1979); Plattform “Ärtzefür das Leben” v Austria (1988); RAI, Allmond and 'Negotiate Now' v United Kingdom (1995); Christians against Racism and Fascism v United Kingdom (1980) and Adaly v. Turkey (2005). For associations, see United Communist Party and Others v Turkey (1998) and Grande Oriente d'Italia di Palazzo Giustiniani v Italy (2001).

${ }^{31}$ Christians against Racism and Fascism v. United Kingdom,..., pgs. 148-149.

${ }^{32}$ Christians against Racism and Fascism v. United Kingdom,..., pgs. 148-149.
} 
Article 11 sometimes requires positive measures to be taken, even in the sphere of relations between individuals. ",33

Once defined the content of the right and defined the locus standi, we should research into the exceptions established by the article 11.2 ECHR. The ECtHR is very clear with these exceptions to the right to freedom of assembly, stating that these "are necessarily restrictive and must be interpreted narrowly." 34 In order to identify the content of these exceptions in a more accurate way it is essential to look into the case-law. From it, we are able to define in a more accurate way the standards of protection established by article 11 of the ECHR.

The ECtHR, before analyzing whether the restrictions fulfill the requirements established by article 11 paragraph 2 , must decide whether such limitations to the right to peaceful assembly constitute an interference. An interference refers to restrictions, conditions or penalties imposed, and sometimes, the existence of a Law may constitute an interference even if not applied in the situation in question. ${ }^{35}$

Once the Court has identified an interference, in our case, with the freedom to peaceful assembly it will analyze the following standards:

\section{A. Prescribed by Law}

The first step taken by the Court is to consider whether the interference with the right to peaceful assembly has been prescribed by Law. In Silver and Others United Kingdom (1983) it is clear that the interference must be based in domestic Law ${ }^{36}$. In fact, not only it must be in accordance with domestic Law, but such Law must be of a certain quality. For a Law to be of a certain quality, it must be (1) compatible with the Rule of Law. The Law must be (2) accessible, meaning that "the citizen must be able to have an indication that is adequate in the

\footnotetext{
33 European Court of Human Rights (First Section), Case of Plattform 'Ärtzefür das Leben' v Austria, (Application no. 10126/82), 21 June 1988, para. 32.

${ }^{34}$ European Court of Human Rights (First Section), Case of Stankov and the United Macedonian Organisation Ilinden v. Bulgaria, (Applications nos. 29221/95 and 29225/95), 2 October 2001, para. 84.

35 KORFF, Douwe.: "The Standard Approach under article 8-11 ECHR and Article ECHR). Accessible at: http://ec.europa.eu/justice/news/events/conference dp 2009/presentations speeches/KORFF Douwe a.pdf (visited the 8th March 2016)

${ }^{36}$ European Court of Human Rights (Chamber), Case of Silver and Others United Kingdom, (Application nos. 5947/72; 6205/73; 7052/75; 7061/75; 7107/75; 7113/75; 7136/75), 25 March 1983, para. 86.
} 
circumstances of the legal rules applicable to a given case" ${ }^{, 37}$; and (3) foreseeable, in other words, "formulated with sufficient precision to enable the individual - if need be with appropriate advice - to regulate his conduct. "38 For a measure to be considered foreseeable, the applicant must have been able "to foresee, to a degree that is reasonable in the circumstances, the consequences which a given action may entail". 39

\section{B. Pursue a legitimate aim}

Once the Court has considered that the interference has been prescribed by Law, it goes on to analyze whether the restriction pursues one of the legitimate aims established in paragraph 2 of Article 11. The legitimate aims laid down within the provision are exhaustive. The restriction of such right should be necessary in a democratic society, in the interests of national security or public safety, for the prevention of disorder and crime, for the protection of health and morals or for the protection of rights and freedoms of others. Below we shall examine the exact meaning of these "aims":

i. Necessary in a democratic society.

The Convention requires the Court to analyze whether the interference with the rights established in articles 8, 9, 10 and 11 is necessary in a democratic society, understood as "the only type of necessity capable of justifying an interference with any of those rights is, therefore, one which may claim to spring from 'democratic society'. " ${ }^{40}$ As highlighted in Handyside vs. The United Kingdom (1976), necessary does not stand for "indispensable", neither for "admissible", "ordinary", "useful", "reasonable" or "desirable"; for the Court to consider a restriction as a necessity there must be a "pressing social need" and the limitations must be "proportionate to the legitimate aims pursued". ${ }^{41}$ In fact, there is not a universal definition for a pressing social need however "it will always involve identifying, within the broader sphere of

\footnotetext{
${ }^{37}$ European Court of Human Rights (Plenary), Case of Sunday Times vs. United Kingdom, (Application no. 6538/74), 26 April 1979, para. 49.

${ }^{38}$ European Court of Human Rights (Second Section), Case of N.F. v. Italy, (Application no. 37119/97), 12 December 2001, para. 26.

${ }_{39}$ European Court of Human Rights (Plenary), Case of Sunday Times vs. United Kingdom, (Application no. 6538/74), 26 April 1979, para. 49.

40 European Court of Human Rights, Case of United Communist Party of Turkey and Others v. Turkey, (Application No. 19392/92), 30 January 1998, para. 45.

${ }^{41}$ European Court of Humans Rights, see Case of Handyside v. The United Kindom, 7 December 1976, para.48, Case of Silver v. the United Kingdom, 25 March 1983, para. 97; and Case of RefahPartisi (the Welfare Party) and Others v. Turkey, 13 February 2003, para. 106.
} 
the legitimate aim pursued, the specific societal need to be addressed with a view to protecting public security." 42 The initial assessment regarding whether there is a pressing social need must be carried out by the national authorities, however the last decision is taken by the Court.

As an example, in Dungeon vs. United Kingdom (1981), the claimant alleged before the Court that the legislation criminalizing homosexual activities in Northern Ireland, breached his rights under article 8 of the European Convention. Regarding this matters, the Court considered that within a democratic society some control over homosexual conduct is necessary, however it maintained that in such circumstances there was not "a 'pressing social need' to make such acts criminal offences, there being no sufficient justification provided by the risk of harm to vulnerable sections of society requiring protection or by the effects on the public." ${ }^{43}$ Similarly, in Partidul Comunistilor (Nepeceristi) and Ungureanu v Romania (2005) the applicant alleged before the ECtHR that the refusal of their application to register the Romanian Communist Party as a political party was contrary to the freedom of association (article 11 of the Convention). Within this judgment, the ECtHR considered that ${ }^{44}$ :

\footnotetext{
"The refusal to register a political party met a "pressing social need" must concentrate on the following points:

(i) whether there was plausible evidence that the risk to democracy was sufficiently imminent;

(ii) whether the leaders' acts and speeches taken into consideration in the case under review were imputable to the political party concerned; and

(iii) whether the acts and speeches imputable to the political party formed a whole which gave a clear picture of a model of society conceived and advocated by the party which was incompatible with the concept of a "democratic society".

Its overall examination of the above points must also take account of the historical context in which the refusal to register the party concerned took place (see Refah Partisi [the Welfare Party] and Others, cited above, § 104)".
}

\footnotetext{
${ }^{42}$ European Commission. See Opinion 01/2014 on the application of necessity and proportionality concepts and data protection within the law enforcement sector, adopted in Brussels on 27 February 2014, accessible at: http://ec.europa.eu/justice/dataprotection/article-29/documentation/opinion-recommendation/files/2014/wp211 en.pdf (visited the 7th of may 2016)

${ }^{43}$ European Court of Human Rights (Plenary), Case of Dungeon vs. United Kingdom, (Application no. 7525/76), 22 October 1981, para. 60.

${ }_{44}$ European Court of Human Rights (Chamber), Case of Partidul Comunistilor (Nepeceristi) and Ungureanu v Romania, (Application no. 46626/99), 21 June 1988, para. 48.
} 
ii. In the interests of national security or public safety.

This legitimate aim is often used by the States to justify the restrictions applied upon certain fundamental rights, and the Court usually gives the States a wide margin of appreciation on this matter. In Grande Oriente d'Italia di Palazzo Giustiniani v Italy (2001), the applicant was an Italian masonic association, existing since 1805, which grouped together several lodges. According to the Italian Law, such association was not recognized as a private-law one, and consequently did not have legal personality. On this basis, the applicant association could not submit applications for nominations and appointments (Regional Law No. 34 of 1996), and therefore it considered that this was a breach of its freedom of association. Even though this is not an example of the freedom of peaceful assembly, within this judgment the ECtHR dismissed the application based, among other reasons, that such limitation intended to protect national security and prevent disorder as it was not clear the role played by Freemasons in the country. ${ }^{45}$

iii. For the prevention of disorder and crime.

In order to understand this legitimate aim, we shall make reference to a judgment of the ECtHR: Eva Molnar v. Hungary (2009). In this case, the applicant and other individuals joined a demonstration without prior notification, against the statutory destruction of the ballots, which had already disrupted the city circulation in the streets of Budapest. Against this background, the police decided to break up with the demonstration, therefore the applicant appealed the action and response of the police.

The Court considered that "restrictions on freedom of peaceful assembly in public places may serve the protection of the rights of others with a view to preventing disorder and maintaining the orderly circulation of traffic", and that "to disperse the ensuing demonstration solely because of the absence of the requisite prior notice, without any illegal conduct by the participants, may amount to a disproportionate restriction on freedom of peaceful assembly". However, in this particular case, as the demonstration took place two-months later since the official results of the elections, and blocked a main bridge in central Budapest, the Court ruled that "the essentially disorderly character of this combination of events is therefore so manifest

\footnotetext{
45 European Court of Human Rights (Fourth Section), Case of Grande Oriente d'Italia di Palazzo Giustiniani v. Italy, (Application no. 35972/97), 12 December 2001, para. 21.
} 
that the decision of the police to disband the gathering cannot be said to be at variance with the object and purpose of Article 11 of the Convention." 46

iv. For the protection of health and morals.

Once again, in Handyside vs. The United Kingdom (1976) the Court highlighted the fact that it is impossible to find a common conception of morals in the domestic laws of the different Contracting States as it "varies from time to time and from place to place, especially in our era which is characterized by a rapid and far-reaching evolution of opinions on the subject". Therefore, States are granted a broad margin of appreciation as "[this]authorities are in principle in a better position than the international judge to give an opinion on the exact content of these requirements as well as on the 'necessity' of a 'restriction' or 'penalty' intended to meet them". 47

v. For the protection of rights and freedoms of others.

As stated in Article 11 paragraph 2, it is possible for States to limit the right to peaceful assembly in order to protect and guarantee the rights and freedoms of others. These rights and freedoms refer to those established within the Convention or its Protocols. The balance between the freedom to peaceful assembly and association, with the rest of rights and freedoms which shall be protected by the States is the foundation of a democratic society. As this balancing is complex, "Contracting States must have a broad margin of appreciation in this respect, since the national authorities are in principle better placed than the European Court to assess whether or not there is a "pressing social need" capable of justifying interference with one of the rights guaranteed by the Convention". The Court clearly highlights that "it is a different matter where restrictions are imposed on a right or freedom guaranteed by the Convention in order to protect "rights and freedoms" not, as such, enunciated therein. In such a case only indisputable imperatives can justify interference with enjoyment of a Convention right". 48

\footnotetext{
${ }^{46}$ European Court of Human Rights (Second Section), Case of Eva Molnar v. Hungary, (Application no. 10346/05), 7 January 2009, paras. 34, 36 and 41.

${ }^{47}$ Op. Cit., Handyside v. United Kingdom,..., para. 48.

${ }^{48}$ European Court of Human Rights (Grand Chamber), Case of Chassagnou and Others v. France, (Applications Nos. 25088/94, 28331/95 and 28443/95), 29 April 1999, para. 113.
} 


\section{The principle of proportionality}

As a reminder, interference of the State in the freedom to peaceful assembly not fulfilling the previous requirements will be considered a breach of Article 11. However, it is possible that the ECtHR understands that the limitation to such right fulfills one or more of the previous aims, but for it to be legitimate the Court still has to analyze whether the restriction complies with the principle of proportionality. In Oya Ataman v. Turkey (2007) the applicant, a lawyer and member of the administrative board of the Istanbul Human Rights Association, organized a demonstration - in the form of march - in Sultanahmet Square in Istanbul to protest against plans for F-types prisons. The demonstration had not been previously noticed therefore the police informed the demonstrators via a loudspeaker that they should end the gathering as it was unlawful and was likely to cause public-order problems. However, the demonstrators continued the protest and continued marching towards the police, who dispersed the group by means of a kind of tear gas known as gas spray and arrested thirty-nine demonstrators.

According to the Courts' findings, there was no evidence to prove that the group in question represented a danger to public order, other than disrupting traffic. For this reasons, "where demonstrators do not engage in acts of violence it is important for the public authorities to show a certain degree of tolerance towards peaceful gatherings if the freedom of assembly guaranteed by Article 11 of the Convention is not to be deprived of all substance." On this basis, the Court considered that "the police's forceful intervention was disproportionate and was not necessary for the prevention of disorder within the meaning of the second paragraph of Article 11 of the Convention., ${ }^{49}$

In Cisse v. France (2002), the applicant was a member of a group of migrants without residence permit who decided to organize a collective action in order to draw attention to the difficulties they were having in obtaining a review of their immigration status in France. Their campaign resulted in the occupation of a church by a group of two hundred illegal immigrants, ten of whom went on hunger strike. Therefore, the Police Commissioner ordered their evacuation. The ECtHR found that the evacuation of the church on the basis that the applicant was an illegal (sic)immigrant was not sufficient to justify a breach of her right to freedom of assembly, however due to the deterioration of the health conditions of the applicants and the

\footnotetext{
${ }^{49}$ European Court of Human Rights (Second Section), Case of Oya Ataman v. Turkey, (Application no. 74552/01) 5 March 2007, paras.41, 42 and 43 .
} 
wide margin of appreciation left to States in this sphere, the Court found that the interference with the applicant's right to freedom of assembly was not disproportionate. ${ }^{50}$

In Kudrevičius and Others v. Lithuania (2005), a group of farmers were issued with permits to hold peaceful assemblies in selected areas. Them held a peaceful demonstration which later resulted in major traffic disruptions on three main roads. According to Article 283 $\S 1$ of the Criminal Code, the five applicants who participated in the demonstration, were each given a sixty-day custodial sentence, suspended for one year, and ordered not to leave their places of residence for more than seven days during that period without the authorities' prior agreement. In this judgment, the ECtHR highlighted that:

\begin{abstract}
"the nature and severity of the penalties imposed are also factors to be taken into account when assessing the proportionality of an interference in relation to the aim pursued (see Öztürk v. Turkey [GC], no. 22479/93, § 70, ECHR 1999-VI; Rufi Osmani and Others, decision cited above; and Gün and Others, cited above, $\S 82$ ). Where the sanctions imposed on the demonstrators are criminal in nature, they require particular justification (see Rai and Evans, decision cited above). A peaceful demonstration should not, in principle, be rendered subject to the threat of a criminal sanction (see Akgöl and Göl v. Turkey, nos. 28495/06 and 28516/06, § 43, 17 May 2011), and notably to deprivation of liberty (see Gün and Others, cited above, $\S 83$ ). Thus, the Court must examine with particular scrutiny the cases where sanctions imposed by the national authorities for non-violent conduct involve a prison sentence (see Taranenko, cited above, $§ 87) . " 51$
\end{abstract}

In Bukta and other v. Hungary (2007), the applicants protested in front of the hotel where the reception was to be held as they were contrary to the participation of the Hungarian Prime Ministers' to the Gyulafehérvár National Assembly's due to its negative significance in Hungarian history. The demonstrations were carried out without prior notification, so the police forced the demonstrators to the park next to the hotel as they considered it constituted a risk to the security of the reception. In this case, the ECtHR considered that "in special circumstances when an immediate response, in the form of a demonstration, to a political event might be justified, a decision to disband the ensuing, peaceful assembly solely because of the absence of the requisite prior notice, without any illegal conduct by the participants, amounts to a disproportionate restriction on freedom of peaceful assembly." Moreover, "when there is no

\footnotetext{
${ }^{50}$ European Court of Human Rights (Second Section), Case of Cisse v. France, (Application no. 51346/99), 9 July 2002, paras. 47 to 53 .

51 European Court of Human Rights (Grand Chamber), Case of Kudrevicius and Others v. Lithuania, (Application No. 37553/05), 15 October 2005, para 146.
} 
evidence to suggest that the applicants represented a danger to public order beyond the level of the minor disturbance which is inevitably caused by an assembly in a public place" the police must show a certain degree of tolerance. ${ }^{52}$

\section{The Margin of Appreciation}

In Sunday Times v. The United Kingdom (1979), with reference to its previous Handyside judgment, the ECtHR gives a clear idea of what shall be understood with the term 'margin of appreciation':

The Court has underlined that the initial responsibility for securing the rights and freedoms enshrined in the Convention lies with the individual Contracting States. Accordingly, "Article 10 (2) (art. 10-2) leaves to the Contracting States a margin of appreciation. This margin is given both to the domestic legislator $[. .$.$] and to the bodies, judicial amongst others that are$ called upon to interpret and apply the laws in force."

"Nevertheless, Article 10 (2) (art. 10-2) does not give the Contracting States an unlimited power of appreciation": "The Court ... is empowered to give the final ruling on whether a 'restriction' ... is reconcilable with freedom of expression as protected by Article 10 (art. 10). The domestic margin of appreciation thus goes hand in hand with a European supervision" which "covers not only the basic legislation but also the decision applying it, even one given by an independent court." (Handyside v. the United Kingdom judgment of 7 December 1976, paras. 48 and 49.)

Therefore, this term is used to indicate the measure of discretion with which the different Member States may implement the Convention's standards, taking into account their individual national circumstances and conditions. ${ }^{53}$ This means that States have a certain margin of appreciation when deciding whether it may be legitimate to restrict the rights included in Article

\footnotetext{
52 European Court of Human Rights (Second Section), CaseBukta and Others v. Hungary, (Application No. 25691/04) 17 October 2007, paras. 36 and 37.

${ }_{53}$ Arai-Takahashi, Y. The Margin of Appreciation Doctrine and the Principle of Proportionality in the Jurisprudence of the ECHR.Intersentianv, 2002, p.2.
} 
11. However, what must be clear is that the last decision regarding the margin of appreciation of the States is taken by the Court, body in charge of its supervision. ${ }^{54}$

\section{E. The requirement of prior authorization.}

Finally, in connection to the necessity of authorization, the ECtHR understands that according with the spirit of Article 11 of the Convention, in order to guarantee public order and national security, it is possible for the States to require prior authorization for the holding of meetings. However, "a decision to disband the ensuing, peaceful assembly solely because of the absence of the requisite prior notice, without any illegal conduct by the participants, amounts to a disproportionate restriction on freedom of peaceful assembly." 55 Therefore, as States have the possibility of requiring prior authorization, they may also apply sanctions to whoever participates in demonstrations that do not comply with such requirement. However, such sanction must comply with the principle of proportionality, and even though in Ziliberberg v. Moldova (2004)the Court considered that a short detention of the applicant and a small fine was proportional to the participation in an unauthorized demonstration ${ }^{56}$; it later established in Samüt Karabulut v. Turkey (2009) that "an unlawful situation does not justify an infringement of freedom of assembly and that regulations of this nature should not represent a hidden obstacle to freedom of peaceful assembly as protected by the Convention." 57

Regarding any other restriction or interference with the freedom of assembly and expression, the Court considers that "any measures interfering with freedom of assembly and expression other than in cases of incitement to violence or rejection of democratic principles however shocking and unacceptable certain views or words used may appear to the authorities do a disservice to democracy and often even endanger it." 58

\footnotetext{
${ }_{55}^{54}$ Case of United Communist Party of Turkey and Others v. Turkey.

${ }^{55}$ Case Bukta and Others v. Hungary,..., para. 36.

${ }_{57}^{56}$ European Court of Human Rights (Fourth Section), Case of Ziliberberg v. Moldova (Application No. 61821/00), 1 May 2005.

${ }^{57}$ European Court of Human Rights (Second Section), Case of Samüt Karabulut v. Turkey, (Application No. 16999/04), 27 April 2009, para.35, which refers back to the Case of Oya Ataman, application no. 74552/01, in paras. 38 and 39, and the Case of Balçık and Others v. Turkey, application no. 25/02, para. 49.

${ }^{58}$ Case of Kudrevicius and Others v. Lithuania,..., para. 145.
} 
To conclude, as seen above, States have both positive and negative obligations. Therefore, apart from guaranteeing the freedom of peaceful assembly, they must also avoid applying "unreasonable indirect restrictions upon that right" 59 and protect individuals from arbitrary interferences of the public authorities in the exercise of the rights protected.

${ }^{59}$ European Court of Human Rights (Second Section), Case of Nurettin Aldemir and Others v. Turkey (Applications Nos. 32124/02, 32126/02, 32129/02, 32132/02, 32133/02, 32137/02 and 32138/02), 2 June 2008, para. 41. 


\section{Conclusions}

1. The Public Safety Organic Act 4/2015 was enacted by the Spanish Government using its absolute majority in the Congreso de los Diputados and the Senate. Even though there was a strong opposition coming from all parties present in the Chamber, there was no real discussion and the Act was finally passed with the only support of the deputies of the Popular Party. As a result, more than 50 deputies from diverse parties submitted this Act to constitutional appeal. Consequently, we may affirm that this process did not comply with the democratic principle.

2. We are not the first in reporting the disproportionate and unnecessary legislation passed by the Spanish Government. In fact, the Council of Europe had already criticized, from the very beginning, the preliminary draft of the Public Safety Organic Act, as it considered that it established disproportionate sanctions which violated fundamental rights, essential in a social and democratic State of Law. Similarly, diverse institutions and international organizations such as the United Nations, Amnesty International, the International Press Institute, among others, have stressed that the PSOA may jeopardize the freedom of information and peaceful assembly. Moreover, this legislation is a clear testimony of the 'democracy backlash' in the Spanish State, which theoretically proclaims as the highest values of its legal orders, liberty, justice, equality and political pluralism. Consequently, this Act is a clear limitation of the rights and liberties of the Spanish citizens, as its affects basic rights such as the right to obtain the effective protection from the Judges and Courts; the right to be presumed innocent; legal certainty, the right and freedom of information, and in particular the right and freedom of association and assembly.

3. As we have seen previously, in accordance with the case-law of the European Court of Human Rights there must be a legitimate aim in order to limit the right to peaceful public assembly. In first place, it must fulfill the principle of necessity, and for it to be necessary, it must pursue a 'pressing social need'. However, we consider that the Spanish society did not show any sign or need of further or future protection of public security. For instance, before the enactment of this Act, there was no evidence to consider that democracy was imminently at risk. Moreover, in the forewording of the Act, the legislator did not mention any need to implement the restrictions that this Act poses.

4. In particular, article 23 of the PSOA establishes the possibility of dissolving demonstrations when these affect the regular transit of vehicles on public roads. In this regard, we would like to highlight that this is absolutely contrary to the case-law of both the ECtHR and 
the STC. From what we have said up to know, it is clear that Governments have the obligation of tolerating and facilitating the development of peaceful demonstrations, which will, always, annoy certain groups or ideologies. For this reason, in case demonstrations take place peacefully and respecting the public order, but traffic is disrupted, the ECtHR considers that the dispersal of such protests is contrary to the principle of proportionality. Otherwise, this would result in the deprivation of all the substance of the right to freedom of peaceful assembly. Similarly, as stated above, the STC emphasized that the disruption of traffic or the street invasion may not be used by the Police authorities as an excuse to avoid or bring demonstrations to an end.

5. The Spanish Constitution, in its Article 81.1, states that fundamental rights and public liberties can only be regulated and developed by an Organic Act. Nevertheless, the Private Security Services Act 5/2014 was not passed as an Organic one, and this circumstance poses a legitimacy problem, as the content may affect basic fundamental rights. As an example, this Act empowers private security agents to conduct detentions when working with Public officers, even though they must not be considered as public authorities. These personnel, have no specific formation in Law and, particularly, in constitutional rights. As a consequence, the fundamental right to personal freedom might be seriously affected as it may be restricted by people without the basic necessary knowledge to enforce it.

6. According to the data contained in the annex, the Courts have recognized that the majority of the 447 arrests related to the mobilizations of $15 M$ in 2013 were arbitrary. Despite the fact that the level of protests has decreased in the following years, the sanctions increased in 2014. Between 2011 and May 2015 with the previous version of the Public Safety Organic Act of 1992, the Government imposed almost 2,000 administrative sanctions. Surprisingly, since July 2015 until nowadays the sanctions reach a total of 40,000 .

7. This Act may affect not only Spanish journalists by tightening their freedoms when performing their work, but also citizens by classifying as misdemeanors for example, the lack of respect to police officers, taking pictures or recording agents or even expressing their dissatisfaction orally or by means of virtual platforms like Facebook or Twitter. 


\section{Annex I. News dossier}

To complement the legislative and jurisprudential vision of the new wording of the Public Safety Organic Ac, we thought it would be useful to identify the real application of this Act, mapping news about it. This analysis seeks to measure the real impact of PSOA before and after it came into force in Spain. This work has been done by using tabs. Each tab is distributed in one page and contains a brief summary of the news. We have collected news from years before the current version of the PSOA entered into force, to illustrate the state of affairs that leaded to the modification performed by the Government in 2015. 
News from 2013

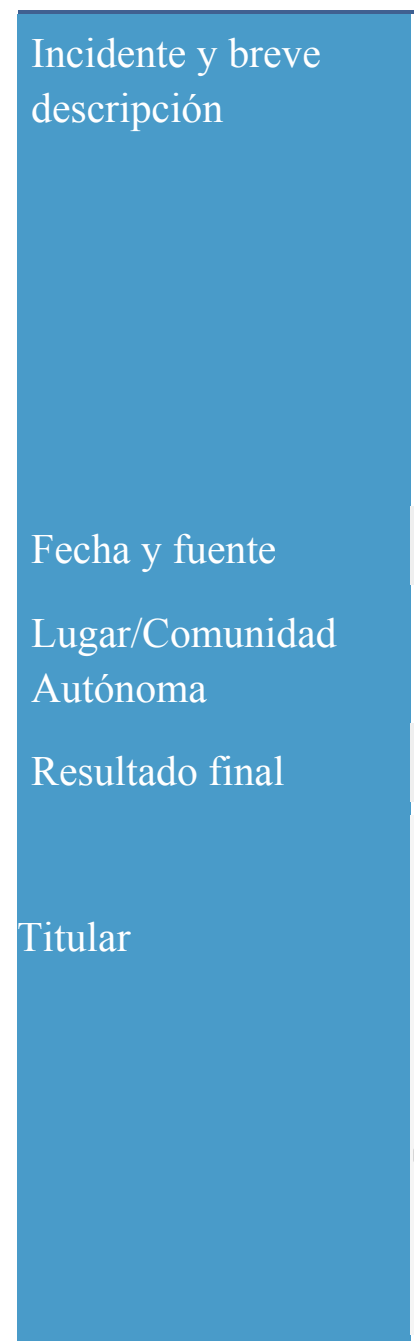
"Ninguno de los 447 detenidos en movilizaciones del 15 M en Madrid ha sido"

Desde el nacimiento del movimiento, el 15 de mayo de 2011 no se ha condenado a ninguno de los 447 detenidos en Madrid por delitos penales. Según los letrados que llevaron la causa la justicia "está reconociendo que la mayoría de detenciones y sanciones son arbitrarias e injustificadas".

22/05/2013 Eldiario.es

España

No fueron condenados

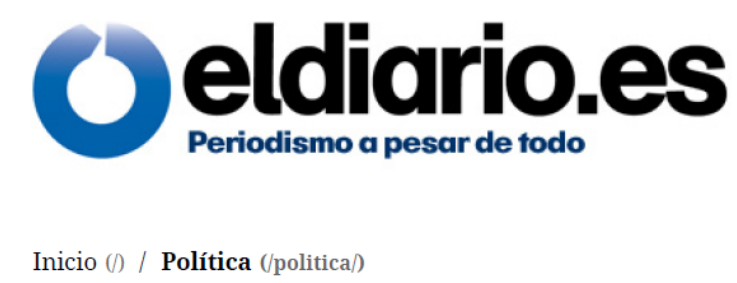
Ninguno de los 447 detenidos en movilizaciones del 15M en Madrid ha sido condenado


Incidente y breve descripción

Fecha y fuente

Titular

\section{"El Consejo de Europa juzga preocupante y desproporción a la ley mordaza".}

El Consejo de Europa advierte al Gobierno Español sobre la aplicación de la Ley de Seguridad Ciudadana, en su Anteproyecto de Ley, por contener sanciones desproporcionadas y sus restricciones a derechos fundamentales como el derecho de reunión y manifestación, y la posible aplicación arbitraria de sus artículos.

04/12/2013 www.lne.es

\section{La Nueva España}

Local Asturias Actualidad Deportes Economía Opinión Ocio Viday E:

Nacional Internacional Sociedady Cultura Sucesos TV Cine

La Nueva Espan̉a „España

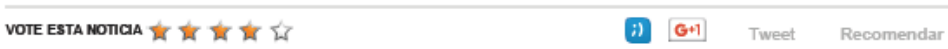

El Consejo de Europa juzga "preocupante y 
News from 2014

\begin{tabular}{|c|c|}
\hline $\begin{array}{l}\text { Incidente y breve } \\
\text { descripción }\end{array}$ & $\begin{array}{l}\text { "Ley de Seguridad Ciudadana Las } \\
\text { manifestaciones prohibidas en infraestructuras } \\
\text { esenciales serán infracciones muy graves". }\end{array}$ \\
\hline & $\begin{array}{l}\text { El Gobierno defiende la nueva ley que pretende sancionar las } \\
\text { acciones violentas, agresivas o coactivas que se produzcan con } \\
\text { ocasión del derecho de manifestación o que en su caso afecten el } \\
\text { la seguridad ciudadana (en el caso de manifestaciones no } \\
\text { comunicadas). Son infracciones muy graves aquellas no } \\
\text { comunicadas o realizadas en infraestructuras o instalaciones de } \\
\text { prestación de servicios básicos. La ley no prohíbe manifestarse ante } \\
\text { el Congreso o el Senado siempre que sea comunicada y } \\
\text { desarrollada de manera pacífica (serán infracciones leves). }\end{array}$ \\
\hline Fecha y fuente & 14/07/2014 abc.es \\
\hline Lugar/Comunidad & España \\
\hline $\begin{array}{l}\text { Autónoma } \\
\text { Infracción }\end{array}$ & Infracciones graves y leves \\
\hline Titular & $\begin{array}{l}\text { Las manifestaciones prohibidas en } \\
\text { infraestructuras esenciales serán infracciones } \\
\text { muy graves }\end{array}$ \\
\hline
\end{tabular}




\begin{tabular}{|c|c|}
\hline $\begin{array}{l}\text { Incidente y breve } \\
\text { descripción }\end{array}$ & $\begin{array}{c}\text { ¿Qué será sancionado a partir de ahora en las } \\
\text { protestas y manifestaciones?" }\end{array}$ \\
\hline & $\begin{array}{l}\text { El Congreso de los Diputados aprobó el Proyecto de Ley Orgánica } \\
\text { de protección de la seguridad ciudadana, calificada como "ley } \\
\text { mordaza" por la oposición y movimientos sociales. La nueva ley } \\
\text { legaliza las devoluciones en caliente en la frontera con Marruecos } \\
\text { la cual para el Comisario de Derechos Humanos del Consejo de } \\
\text { Europa NilsMuiznieks va en contra de la Jurisprudencia del } \\
\text { Tribunal Europeo de Derechos Humanos. La oposición ha } \\
\text { criticado la "discrecionalidad" que facilita el redactado de la ley, } \\
\text { como sucede por ejemplo el punto que castiga la "falta de } \\
\text { consideración" a un policía. "¿Será obligatorio hablarle de usted?", } \\
\text { se ha preguntado durante la tramitación parlamentaria el diputado } \\
\text { de la Izquierda Plural Ricardo Sixto. }\end{array}$ \\
\hline Fecha y fuente & 11/12/2014 Lamarea.com \\
\hline $\begin{array}{l}\text { Lugar/Comunidad } \\
\text { Autónoma }\end{array}$ & España \\
\hline Resultado final & La ley Mordaza entro en vigencia el 01 de Julio del 2015. \\
\hline & Sociedad Cultura \\
\hline
\end{tabular}

Sociedad

\section{¿Qué será sancionado a partir de ahora en protestas y manifestaciones?}

- La mayoría absoluta del Partido Popular ha aprobado este jueves en solitario en el Congreso la Lej de Seguridad Ciudadana, calificada por la oposición y los movimientos sociales como 'ley mordaza' 11 diciembre 2014

18:20

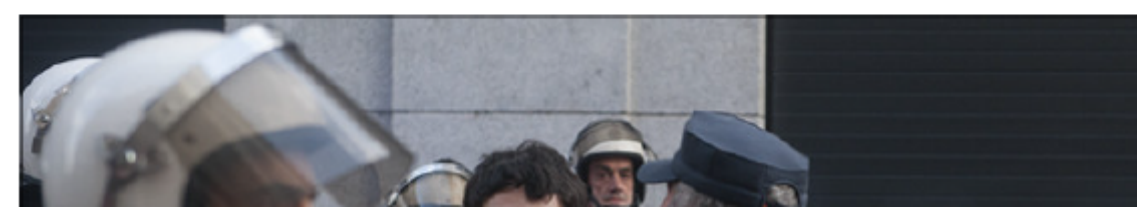


News from 2015

\begin{abstract}
Incidente y breve
descripción

\section{“La ominosa Ley Mordaza de España".}

Un grupo llamado 'No somos delito', proyectó un holograma de los manifestantes frente al edificio del Parlamento de Madrid. Hasta ese momento las protestas virtuales bajo la forma de hologramas no eran ilegales, hasta la entrada de la Reforma de la Ley de Seguridad Social

La ley fue presentada en 2013 por el Gobierno precedido por Mariano Rajoy. Esta ley fue aprobada por la cámara en diciembre de 2013, pese de las quejas presentadas por los demás grupos politicos y de las Naciones Unidas. Se critica que el principal proposito de la ley es ayudar al partido gobernante a mantenerse en el poder y devuelve a España a los oscuros días del régimen de Franco.
\end{abstract}

Fecha y fuente

Lugar/Comunidad Autónoma

Rango de sanción prevista por la ley

Titular

\section{3/05/2015 CTXT.es/ New York Times}

España

Multa de 30.000 a 60.000 euros

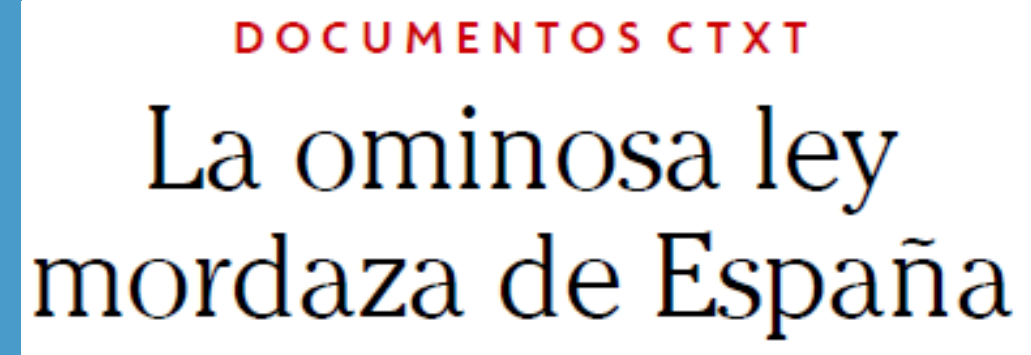

(C) THE NEW YORK TIMES 


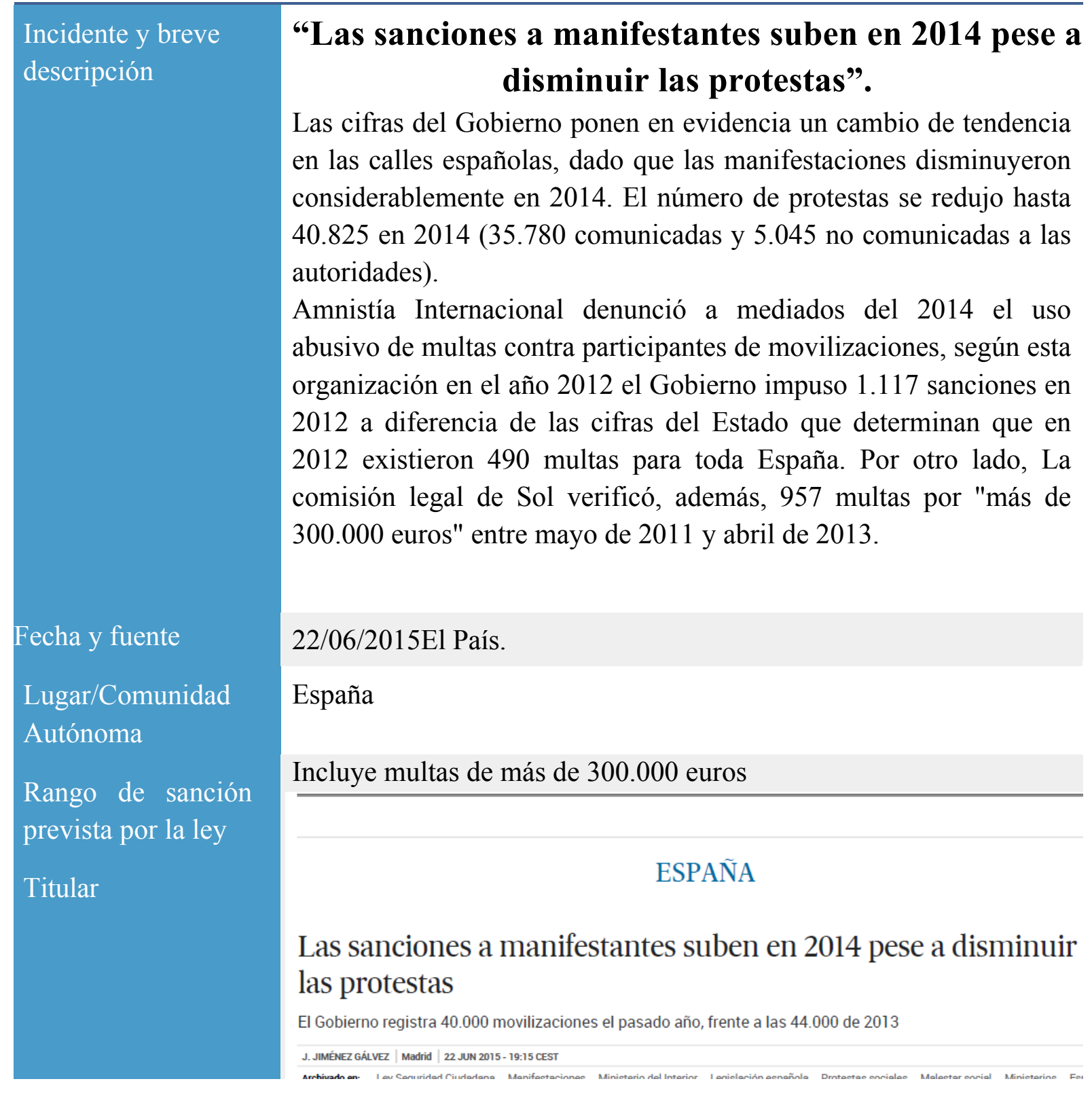




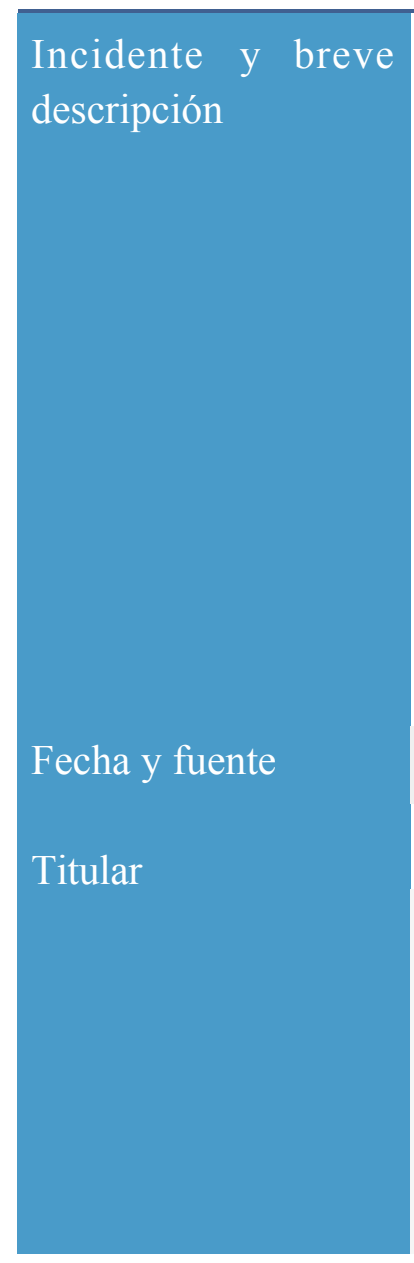

\section{"Los siete derechos fundamentals quell limita la Ley Mordaza"}

Tras la entrada en vigor de la Ley de Seguridad Ciudadana, denominada por la sociedad, "LeyMordaza", se han sucitado distintas quejas sobre su desproporcionalidad y limitación de derechos fundamentales, como el derecho a la no discriminación, al derecho de defense y de presunción de inocencia, la seguridad jurídica, a la libertad y al derecho a la información entre otros, por su amplia lista de infracciones y sanciones, como la prohibición de grabar a policías, la creación del Registro de Infracciones contra la Seguridad Ciudadana, etc.

\section{Oeldicia}

Los siete derechos fundamentales que limita la 'Ley Mordaza' 


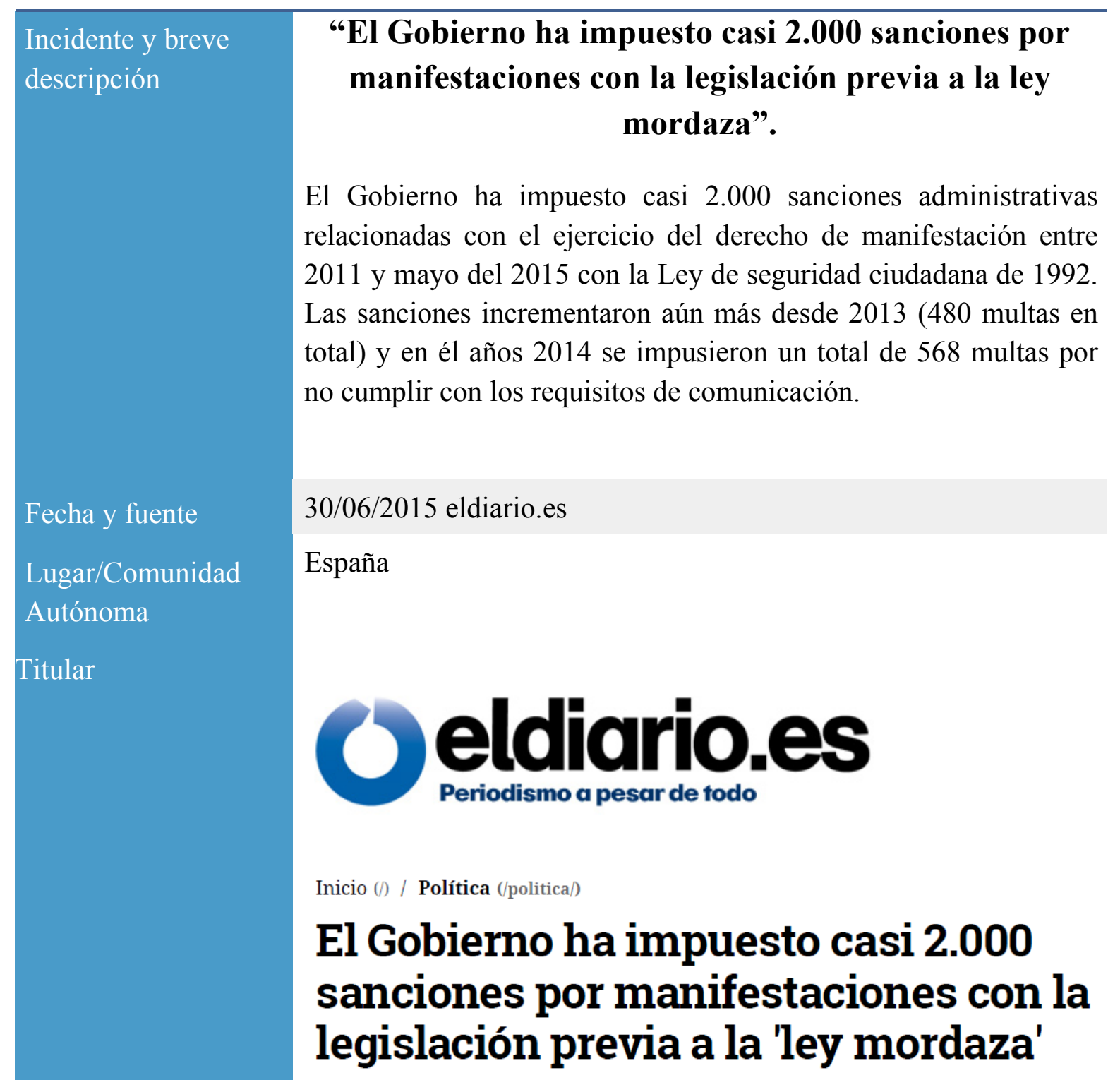




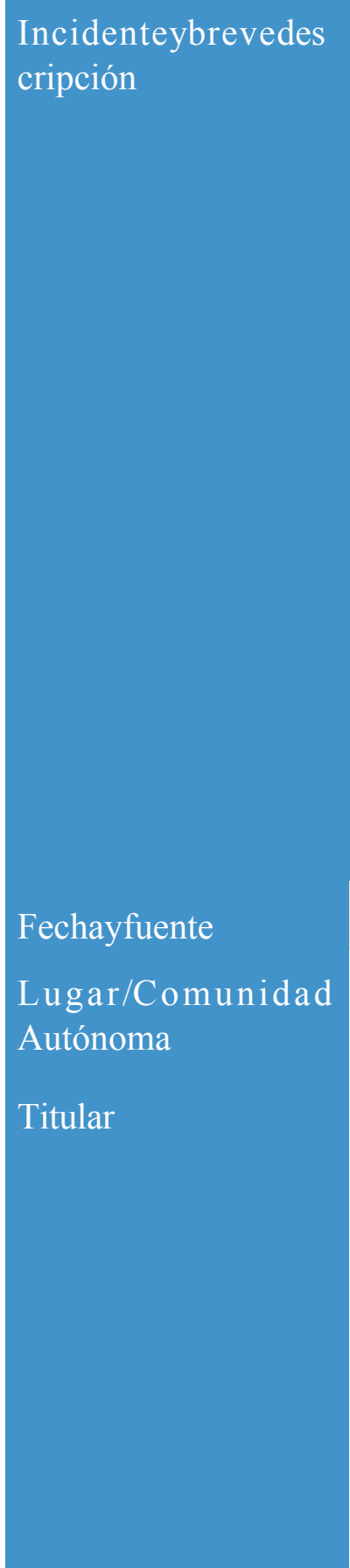

\section{"Ley Mordaza instrucciones de uso".}

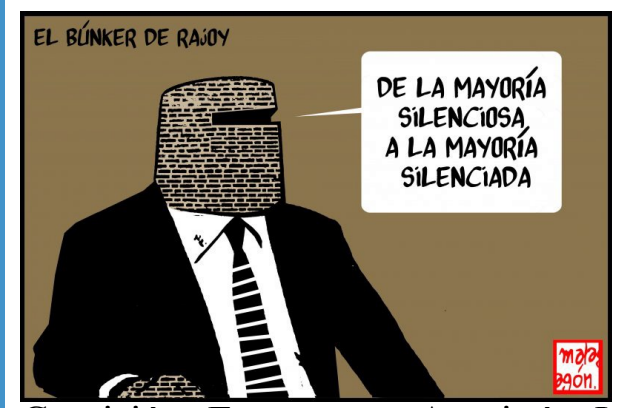

Desde el primero de julio entrada en vigencia la nueva Ley de Seguridad Ciudadana endurece las infracciones y sus correspondientes multas.

La entrada en vigor de la ley Comisión Europea y Amnistía Internacional como una reforma legislativa que pone en riesgo la libertad de información y la protesta pacífica. La Ley Orgánica 4/2015 de Protección de la Seguridad Ciudadana toma como referente la Ley Orgánica 1/1992 sobre Protección de la Seguridad Ciudadana. Y, si se atiende a ambas leyes, encontramos que lo que antes eran sanciones graves, ahora son sanciones muy graves, lo que implica en primer lugar que la multa a pagar será mayor.

17/06/2015 CTXT.es

España

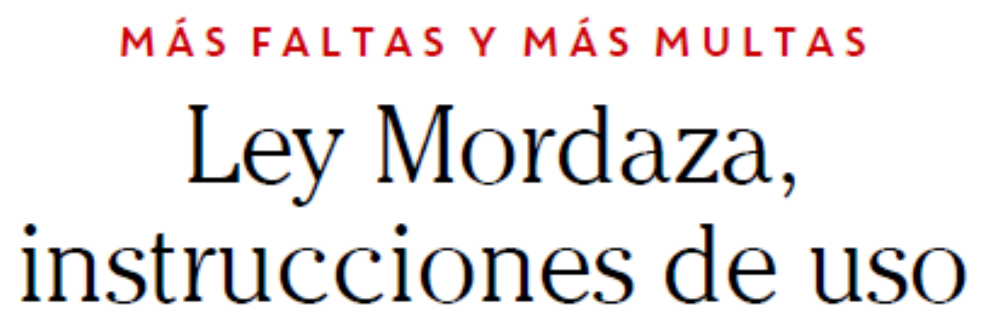

MARÍA NAVARRO 


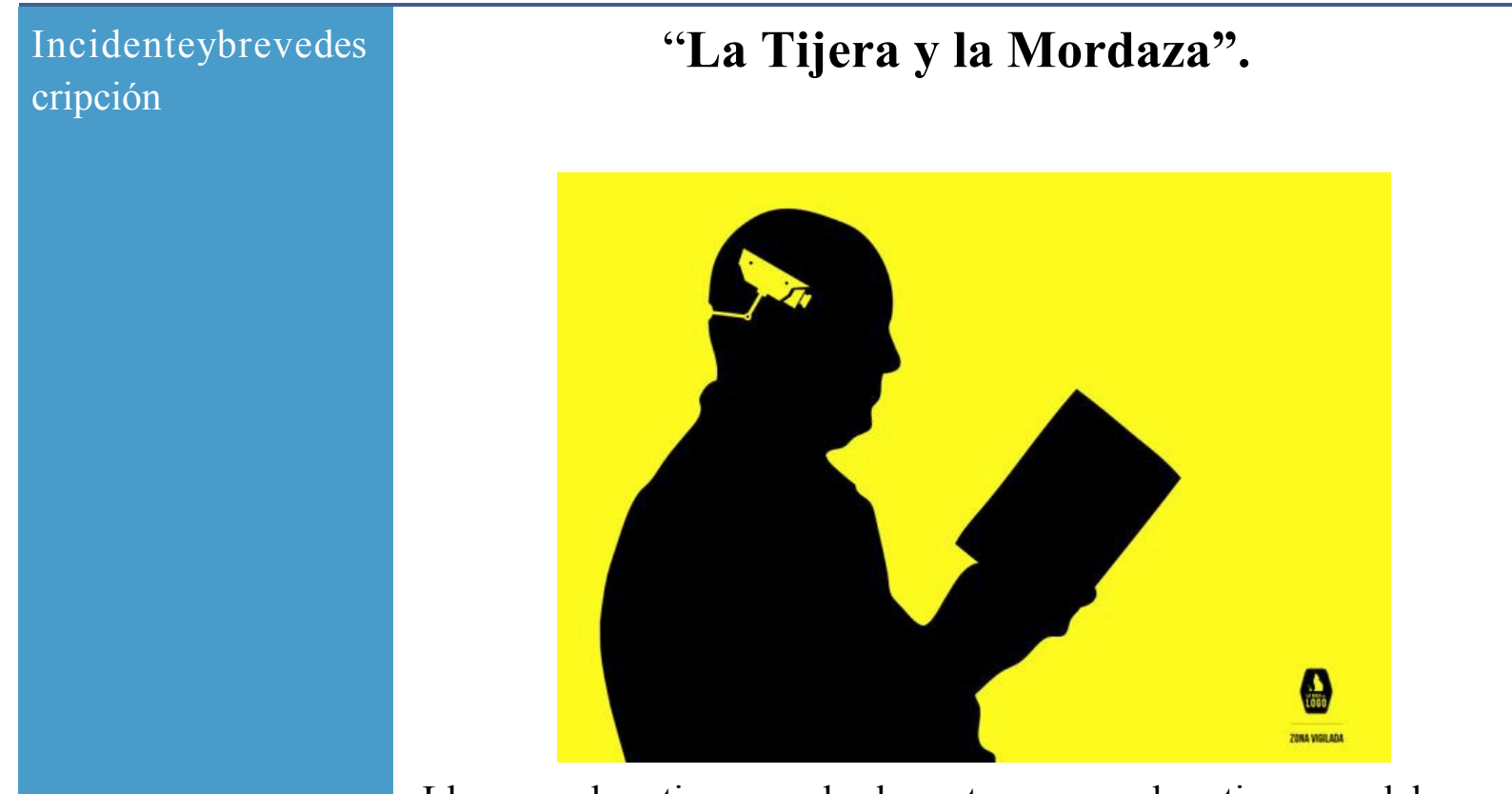

Llegaron los tiempos de la autosensura, los tiempos del neo lenguaje, en el que los muertos de las guerras se llaman daños colaterales y los ladrones son amnistados fiscales. La ley mordaza prohibe protestar en sitios que perturben la seguridad ciudadana. Esa que celebran viendo mil veces Gilda los fantasmas erectos de los censores. ¿Será por que se empieza con la corrección politica y termnina con la censura?.

FechayFuente

Lugar/Comunidad Autónoma

Titular

\section{1/07/2015 CTXT.es}

España

\section{EL DESCONTEXTO}

La tijera y la mordaza 


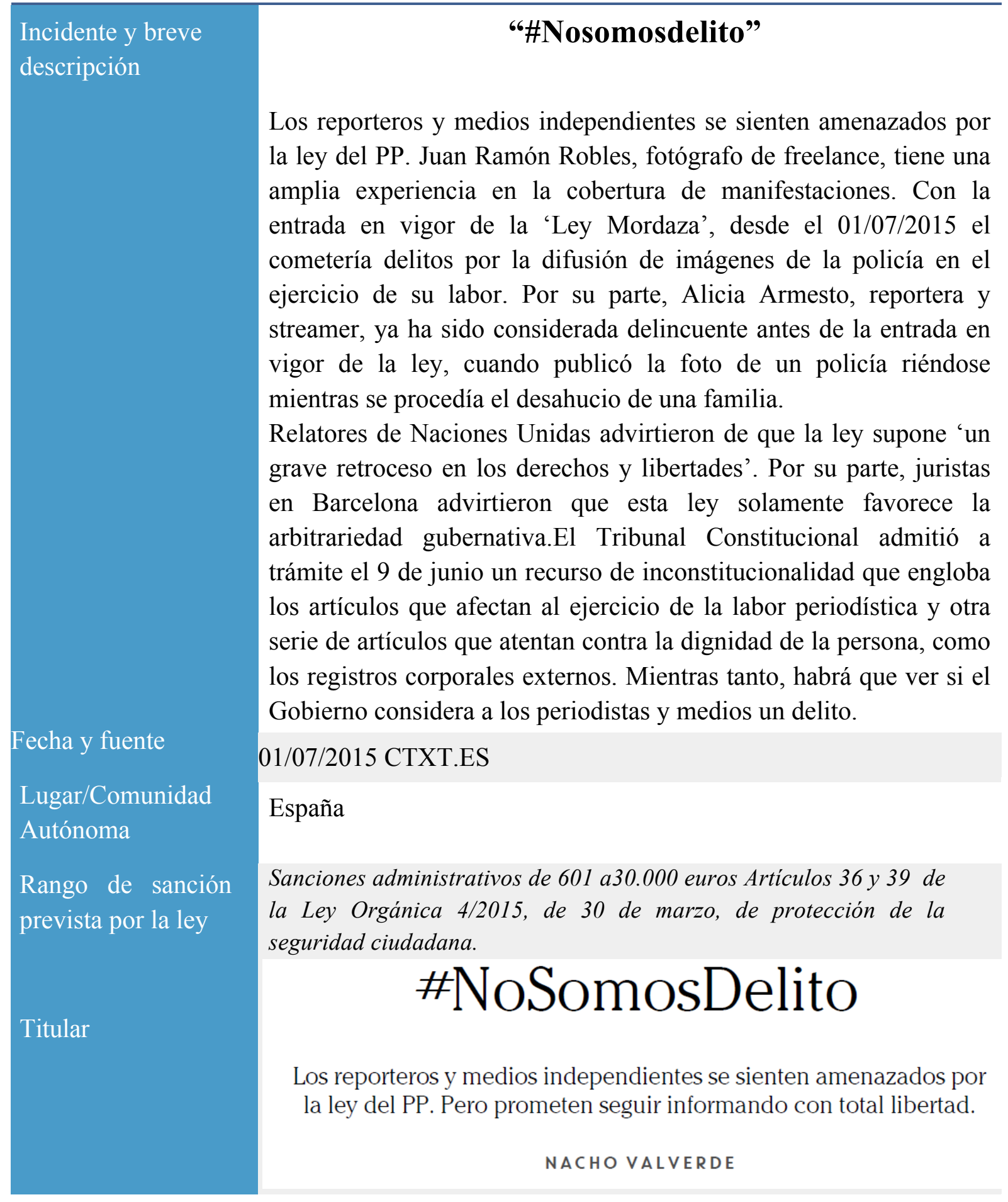




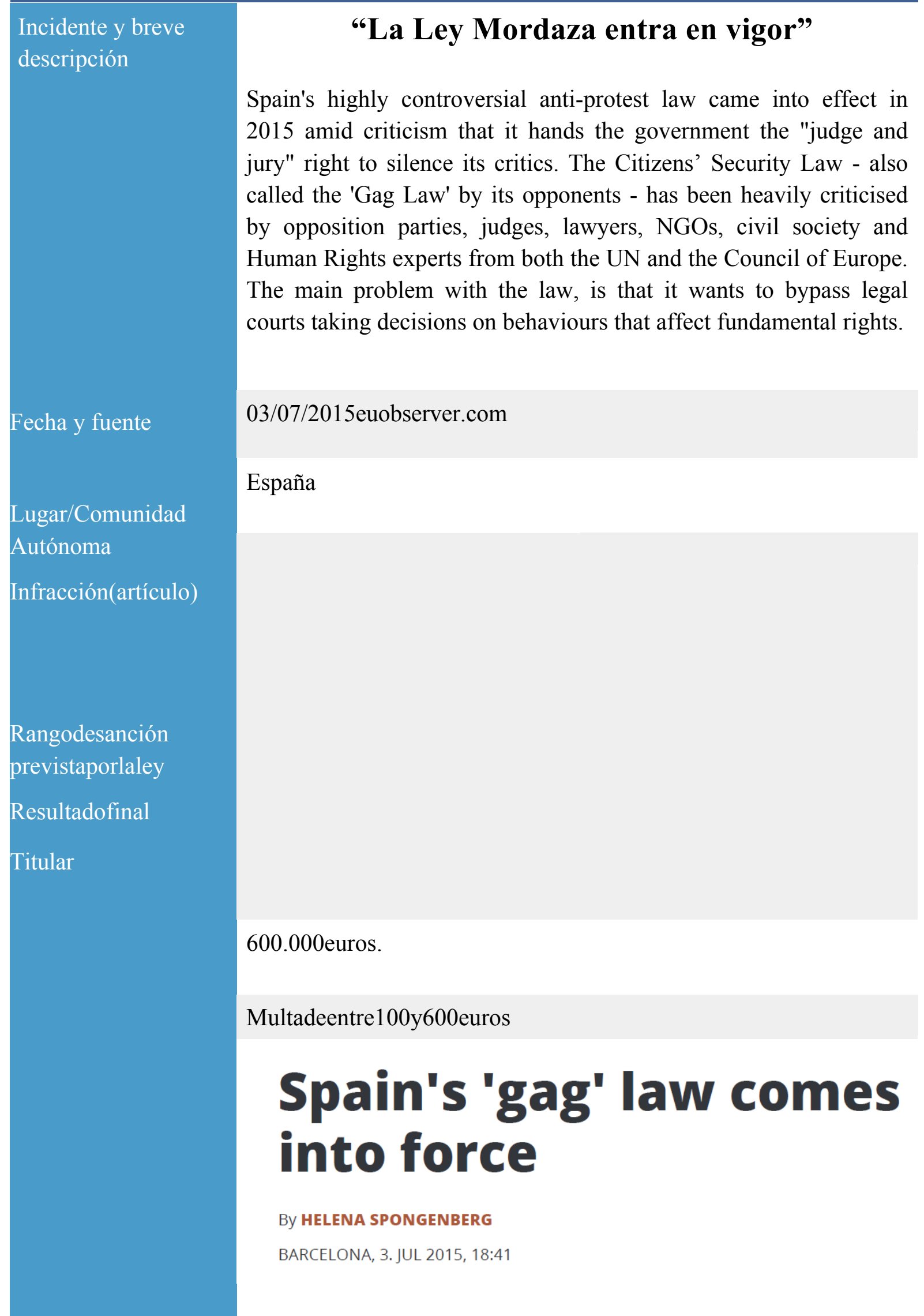




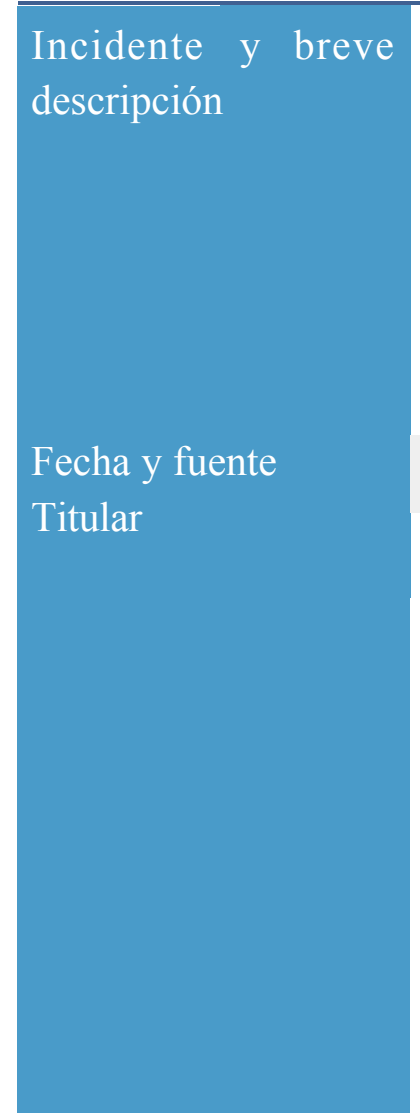

\section{"La ONU externa preocupación por la Ley Mordaza en España".}

El Comité de Derechos Humanos de la ONU, muestra preocupación ante la aprobación de la Ley de Seguridad Ciudadana por el efecto que puede tener ante los derechos de libertad de expresión, asociación y reunión pacífica.

23/07/2015 El informador

\section{La ONU externa preocupación por 'Ley Mordaza' en España}

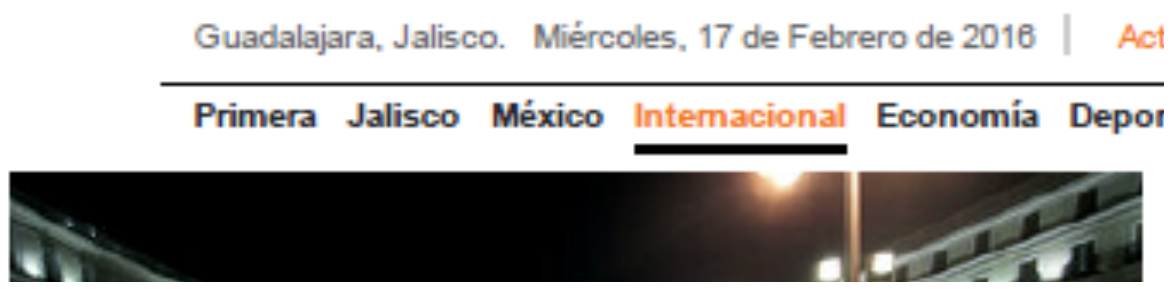




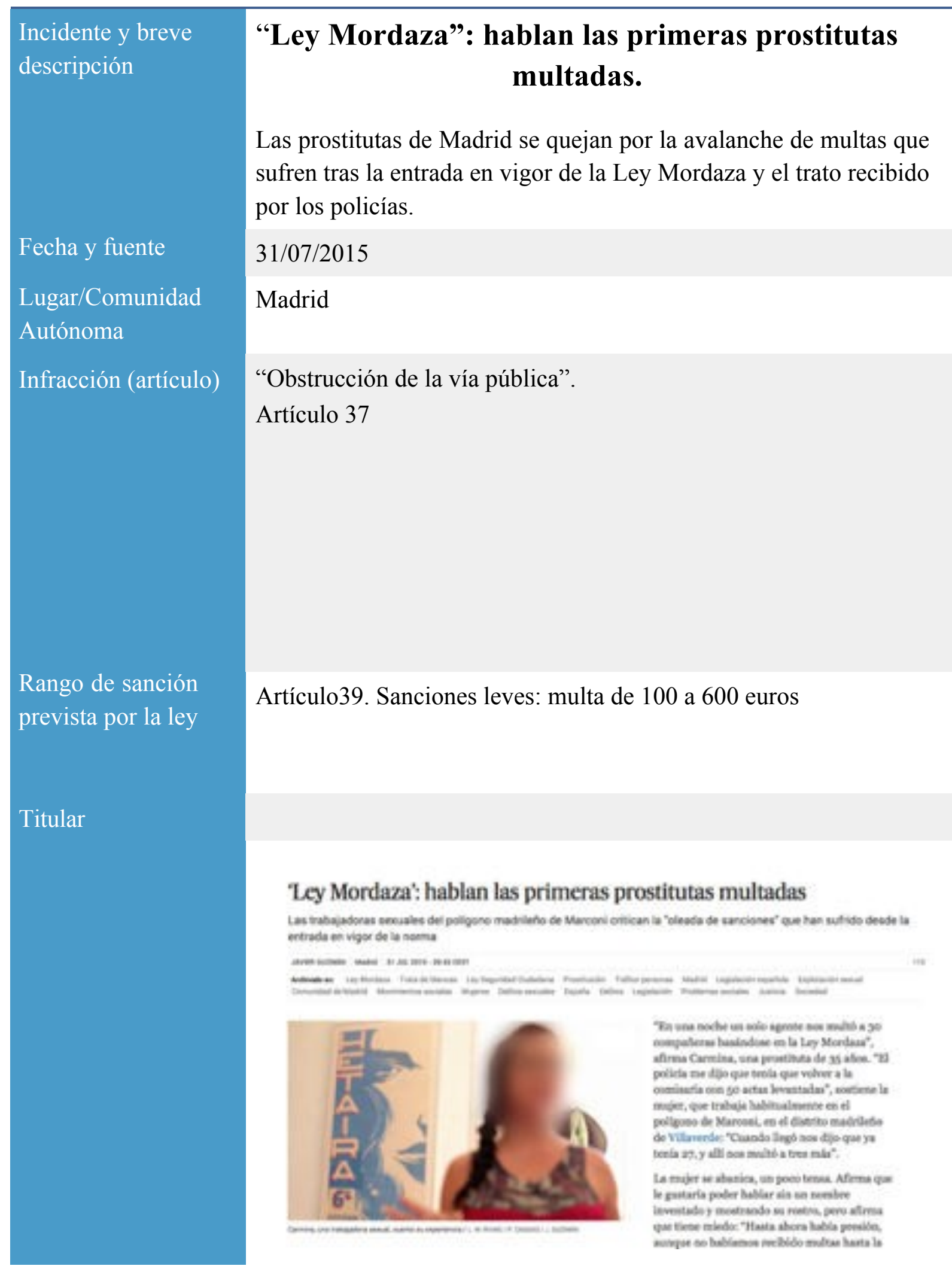




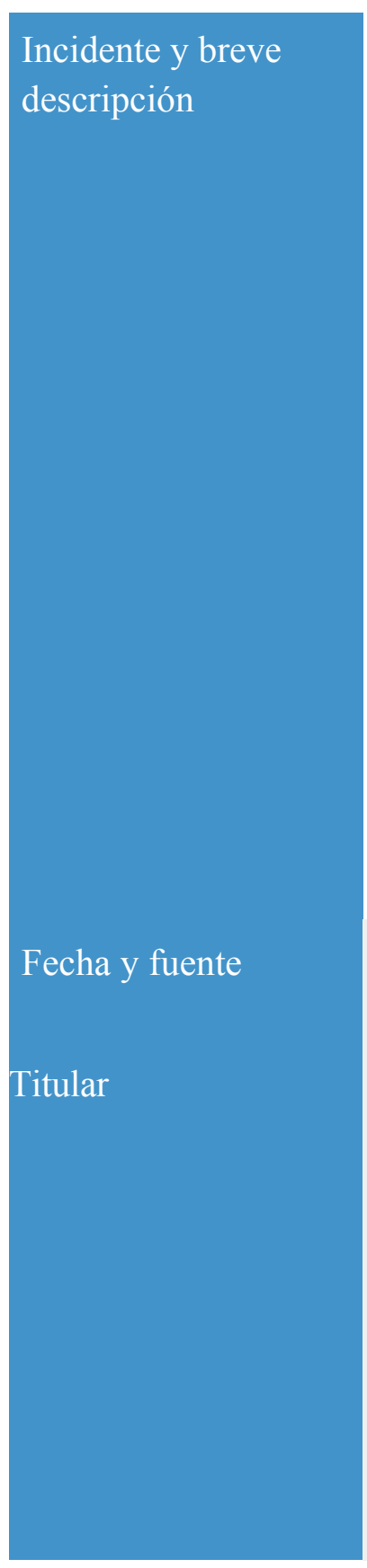

\section{“Javier Ruival habla de la ley mordaza".}

En una entrevista a Javier Ruival el hablo sobre la ley mordaza y a su consideración: “(...) va a ser derogada, y se va a revertir a lo público casi todo lo que se pueda recuperar. Eso lo sabe todo el mundo. Esta gentuza llegó y se creyó que esto era su cortijo y que iba a poder hacer lo que le diera la gana. Si un día les rodearon el Congreso, la gente dijo: ahora vamos a entrar. Y eso es lo que va a pasar. Con tanto hostigamiento han conseguido lo que se merecen, que se vayan a la calle y que empiecen otra vez. Nunca empezarán desde cero porque tienen mucho dinero y mucha influencia, pero los apaleados se van a meter ahora hasta la cocina del Congreso y eso me provoca mucha esperanza. Lo de la Ley Mordaza es algo transitorio que terminará derogándose porque incluso desde Naciones Unidas y tribunales internacionales han dicho que es ilegal".

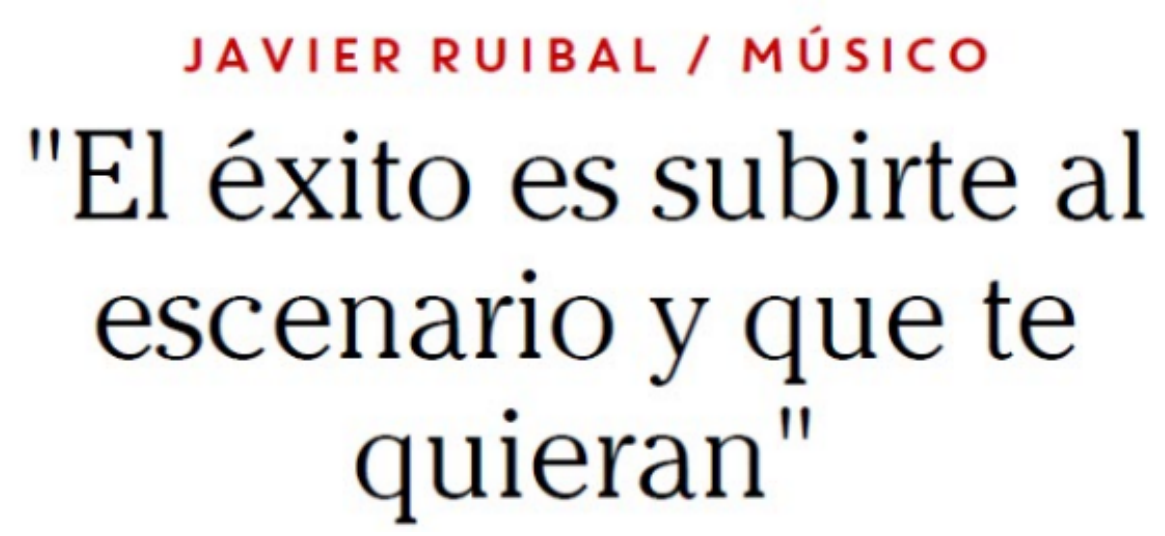




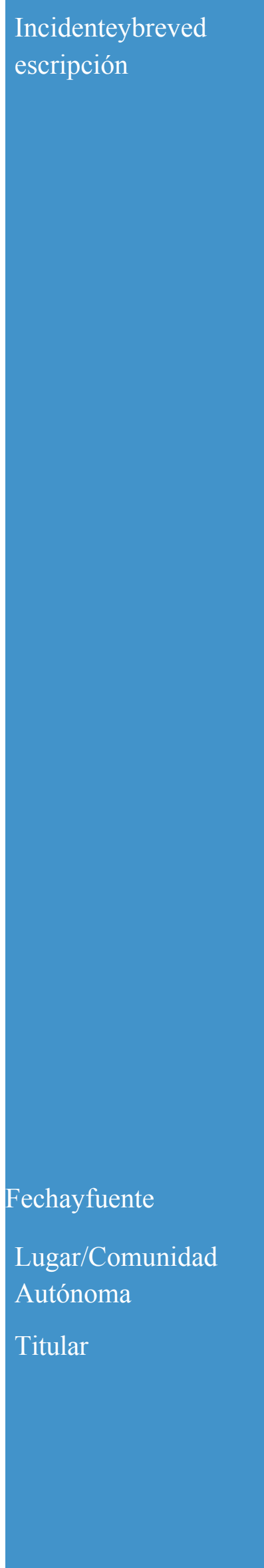

\section{"Por qué los medios españoles son los Peores de Europa y qué está haciendo para mejorarlos".}

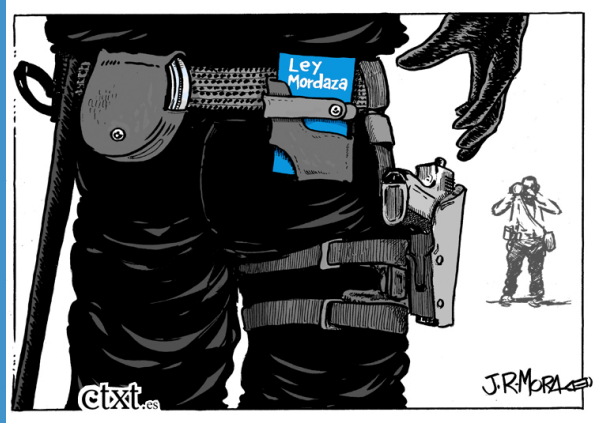

Los medios de comunicación en España han contribuido a difundir a idea de que no hay hechos incontestables sino visiones parciales de la realidad. A primera vista el panorama de los medios de comunicación es amplio los 47 millones de habitantes pueden elegir entre 85 periódicos. Los españoles desconfían de sus periodistas casi tanto como de sus políticos. El auge del descontento electoral, ha cambiado el mapa político del país. El gobierno del PP se ha valido de su mayoría absoluta en las Cortes para aprobar la polémica nueva Ley de Seguridad Ciudadana, conocida como la 'ley mordaza'. La ley, que entró en vigor el 1 de julio, no sólo limita el derecho de los ciudadanos a protestar en persona o por escrito, en forma impresa o digital, sino que también frena la capacidad de los medios de comunicación para cubrir esas protestas. Miguel Mora, ex periodista de El País, escribió en la revista italiana Internazionale que la ley "contiene 44 artículos que conceden al Gobierno la potestad de multar a los ciudadanos con sanciones económicas que oscilan entre los 100 euros y los 600.000 por faltas administrativas agrupadas en tres categorías." El propósito de laley, añadió, es eludir el sistema judicial. "En efecto nos devuelve a los tiempos de la dictadura franquista y nos mete de lleno en un estado policial". La ley mordaza ha provocado protestaspor parte de entidades tan diversas como lasNaciones Unidas, el Instituto Internacional de Prensa, y The New York 16/10/2015 CTXT.es

España

Por qué los medios españoles son los peores de Europa y qué se está haciendo para mejorarlos 


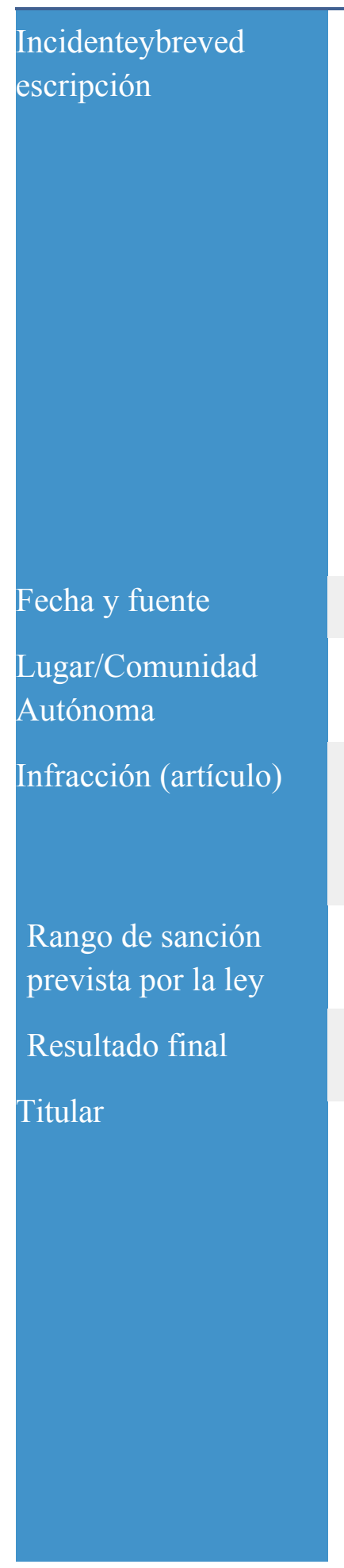

\section{"Nos condenan a seis meses de cárcel por manifestarnos, nos quieren desmovilizar".}

Una jueza condenó a Sergio Patón y a Víctor Rey (activistas) a seis meses de prisión, por cometer delito ante la autoridad en las marchas contra la corrupción, llevadas a cabo en la ciudad de Madrid el 18 de julio del 2013. Su sentencia se basa únicamente en las declaraciones de la policía Nacional. Por su parte, los activistas consideran que son víctimas de un montaje policial ya que no opusieron resistencia ni agredieron a los agentes.

\section{3/11/2015 Eldiario.es}

Madrid, Comunidad de Madrid

Seis meses de prisión y una sanción de 1500 euros

Los acusados no irán a prisión por carecer de antecedentes penales y han interpuesto recurso ante la Audiencia Provincial de Madrid.

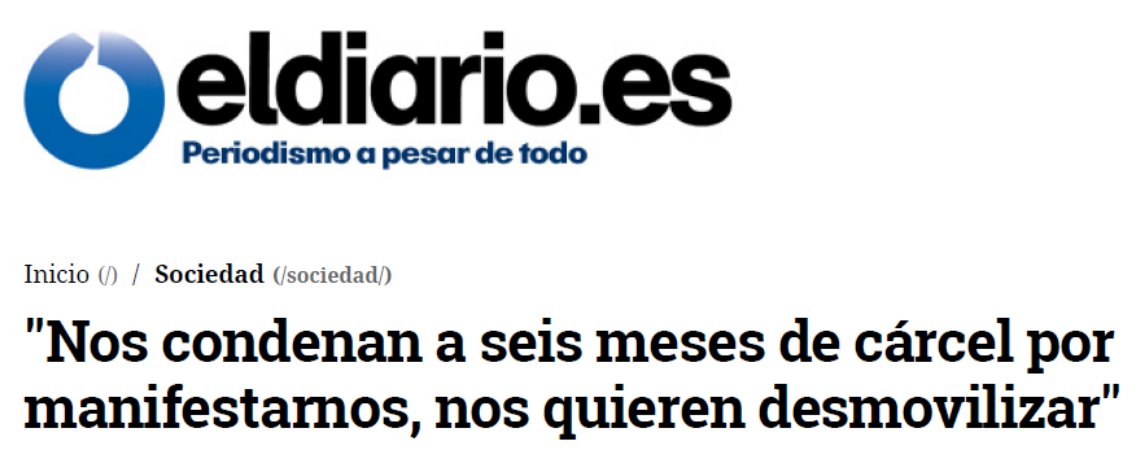




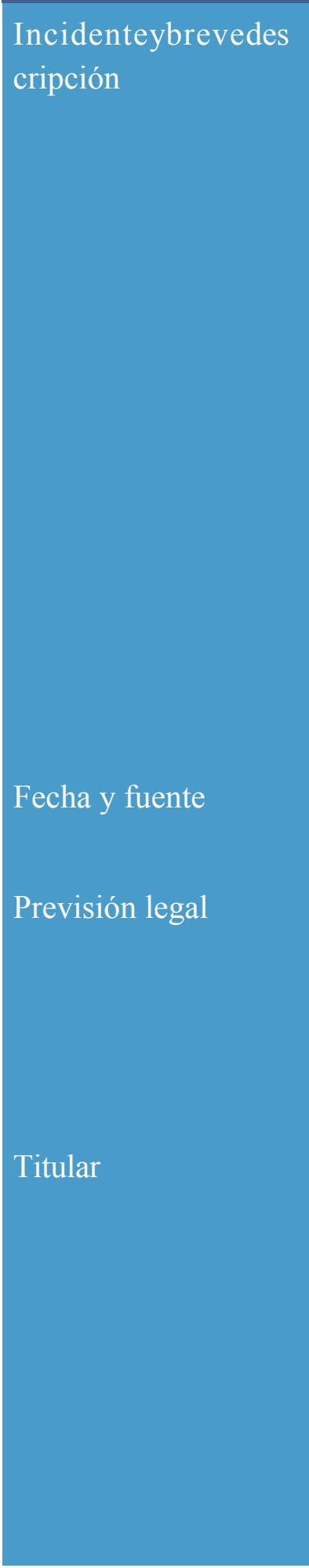

\section{"Presentamos primera demanda ante el Tribunal de Estrasburgo contra la Ley Mordaza".}

DefenderaquiendefiendepresentalaprimerademandaanteelTribunalEu ropeodeDerechosHumanosporlaaplicacióndelanuevaleydeseguridadc iudadana.

El Litigio se apoya en el estatus jurídico de 'victima potencial', como daño inminente que puede suponer la aplicación de la ley Mordaza sobre un derecho protegido por la Convención Europea de Derechos Humanos. La demanda se centra en los abusos que afectan directamente al derecho de la libertad de expresión amparada en la Constitución española. El litigio se presentó de la par con los medios de comunicación Ahötsa (Navarra) y la Directa (Barcelona y Diagonal (Madrid). Esta demanda busca poner en la mira pública la restricción de derechos que supone la reforma a la Ley de seguridad ciudadana, suma del resto de reformas realizadas en 2015 en materia de seguridad

Barcelona 15/12/2015. Defenderaquiendefiende

El derecho a la información vulnerado "La arbitrariedad de artículos como el 36 punto 23 de la Ley Mordaza ya está implicando que en ocasiones algunas personas, sobretodo fotoperiodistas, se vean compelidas por los agentes a dejar de grabar o fotografiar actuaciones policiales por el riesgo a ser sancionadas. Por ese motivo, se considera que las personas que trabajan en el sector del periodismo y audiovisual son un colectivo especialmente afectado por esta disposición, ya que pone en peligro su función principal: informar sobre hechos de relevancia pública".

\section{[]] DEFENDER}

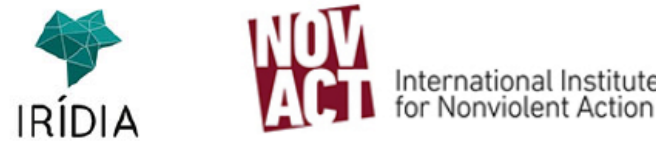

\section{Primera demanda al Tribunal Europeo de Derechos Humanos contra la Ley Mordaza}




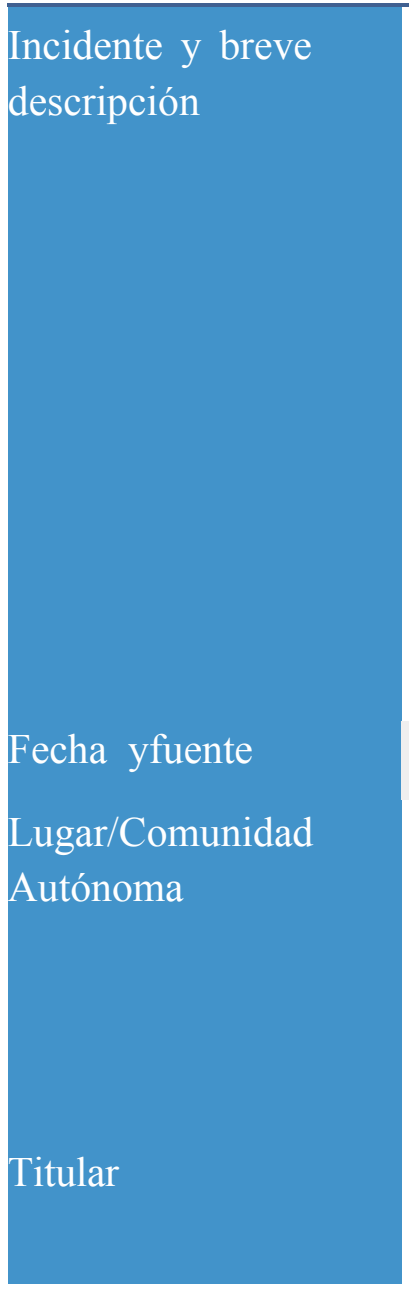

\section{“Journalists take fight against Spanish 'gag law' to European court"}

A group of journalists launched a triple lawsuit at the European court of Human Rights in an attempt to force Spanish MPs to repeal a security law that cracks down on the right to assembly and freedom of expression. The "gag law" introduced modifications set out strict guidelines on when and where protests can take place, stipulating fines of up to $€ 600$ for "disrespecting a police officer" and up to $€ 600,000$ for holding an un authorised protest near key infrastructure such as transport hubs or telecoms installations.

15/12//2015 The Guardian

Madrid

\section{theguardian}

\section{Journalists take fight against Spanish 'gag law' to European court}

Complainants argue law encourages self-censorship and paves way for diminished accountability of police forces in Spain 


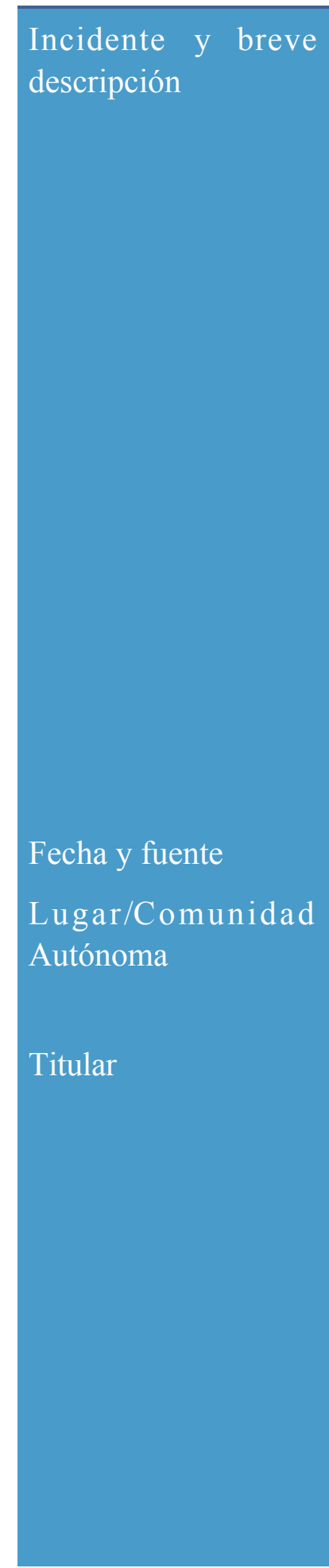

\section{"Las trabajadores sexuales quieren ser escuchadas".}

La asociación Afemtras plantea sus demandas a los paridos politicos. Desde la entrada en vigor de la Ley Mordaza en junio del 2015 llevó a muchas trabajadoras sexuales a unirse al hartarse de ser multadas por policias. Desde que las fuerzas de seguridad empezaron a aplicarles el 36.6 de la ley de seguridad ciudadana "las convierte en delincuentes".El Art. 36.6 que considera infracción grave "la desobediencia o la resistencia a la autoridad o a sus agentes en el ejercicio de sus funciones" y el Art. 37.5 que recoge como infracción leve "ejecutar actos de exhibición obscena". Además, el Art. 36.11 permite perseguir a los clientes ya que penalize como infracción grave "la solicitud o aceptación por el demandante de servicios sexuales retribuidos" cerca de colegios o zonas infantiles o cuando estas conductas puedan generar "un riesgo para la seguridad vial".

18/12/2015 CTXT.es

España

\section{Las trabajadoras sexuales quieren ser escuchadas}

La asociación Afemtras plantea sus demandas a los partidos políticos para el 20-D. La primera, el reconocimiento de sus derechos 
News from 2016

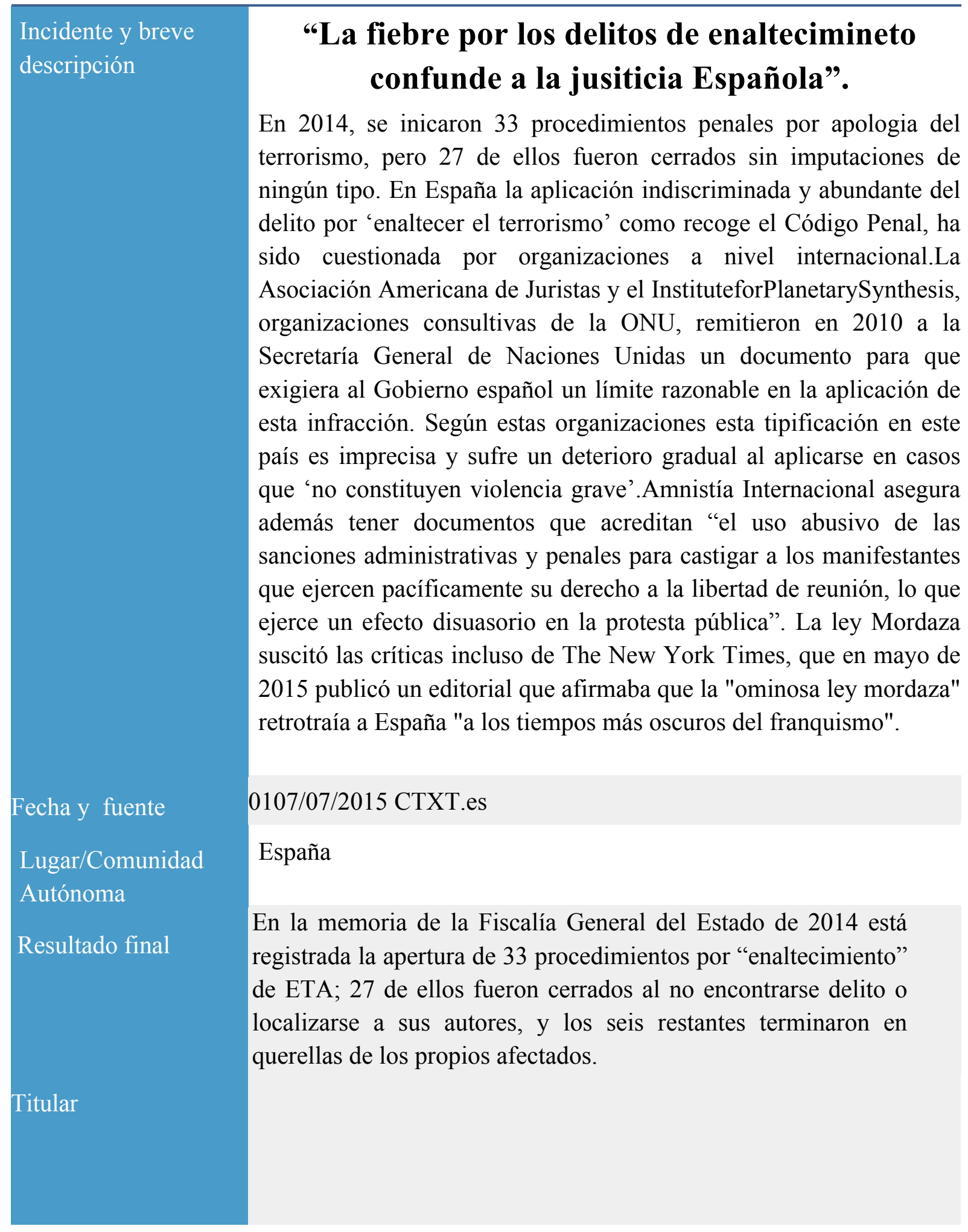




\section{La fiebre por los delitos de enaltecimiento confunde a la justicia española}

Incidente y breve descripción

Fecha y Fuente

\section{"Periodismo Blow Job Grupo Salvaje".}

"Ciertos periodistas de la derecha mediática parecen presos de desenfundrar como los pistoleros de un western crepuscular", es la afirmación de este periodista que analiza la actual realidad de los comunicadores a raíz de la ley mordaza. Misma que impide una defensa limpia que se ve reprimida en el deber de informar. "Entendiendo que la libertad de expresión es un logro jurídico que certifia a un país como Estado democrático modeno y establece el derecho fundamental para mantere el equilibrio entre el poder y la ciudadania y el libre ejercicio de la manifestación política, el arte, la literature y la prensa". Este derecho ha sido puesto en tela de juicio desde la vigencia de la Ley mordaza, la caza al hombre del caso Zapata o la detencion de Cesar Strawberry. Algunas recientes sentancias en los límites de la censura y de la repressionindeológica, es una doble vía de medir la persecucion de manifestaciones en las redes sociales.

$10 / 02 / 2016$

España 


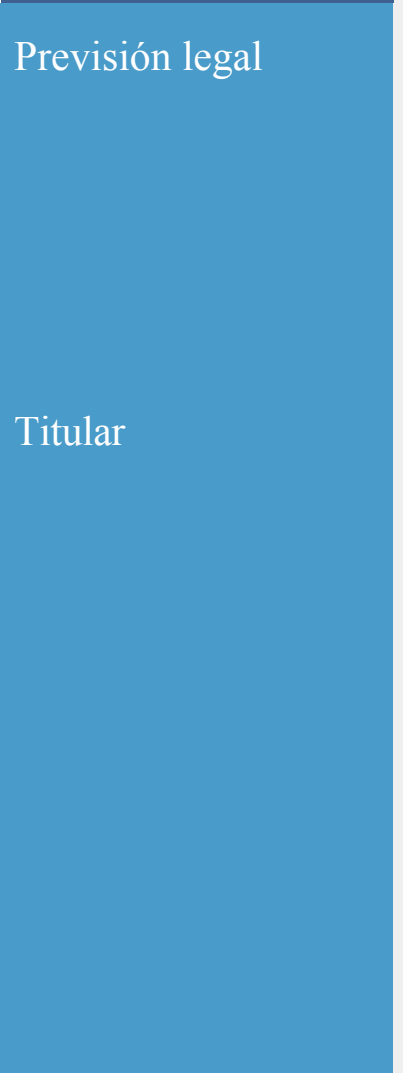

El artículo 20 de la Constitución Española establece los derechos a "expresar y difundir libremente los pensamientos, ideas y opiniones mediante la palabra, el escrito o cualquier otro medio de reproducción. A la producción y creación literaria, artística, cientifica y técnica. A la libertad de cátedra. A comunicar o recibir libremente información veraz por cualquier medio de difusión".

\title{
PERIODISMO BLOW JOB
}

\section{Grupo Salvaje}

\author{
PILAR RUIZ
}

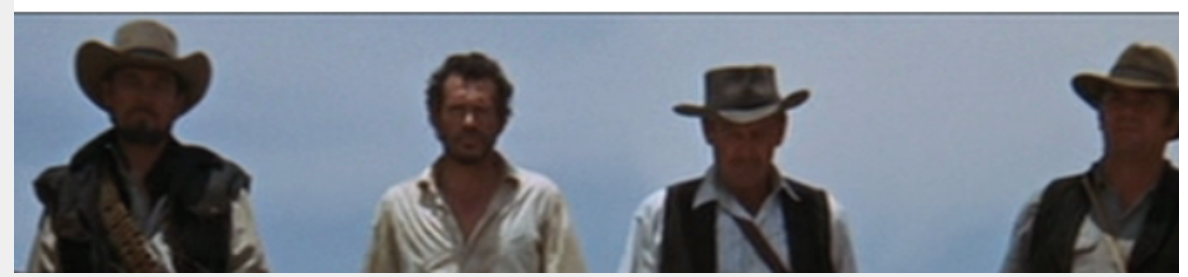


Lugar/Comunidad

Autónoma

Titular

Madrid España

\section{LAVANGUARDIA $\mid$ Política}

三 A AlMinuto Internacional Política Opinión Vida Deportes Economía Local Gente Cultura Sucesos Temas

Politica Elecciones

El Congreso tramita las propuestas para derogar la Lomce, la ley mordaza y la reforma laboral

Podemos presidirá la Comisión de Empleo; el PP, la Constitucional; el PSOE, la de Justicia, y Ciudadanos, la de Presupuestos 


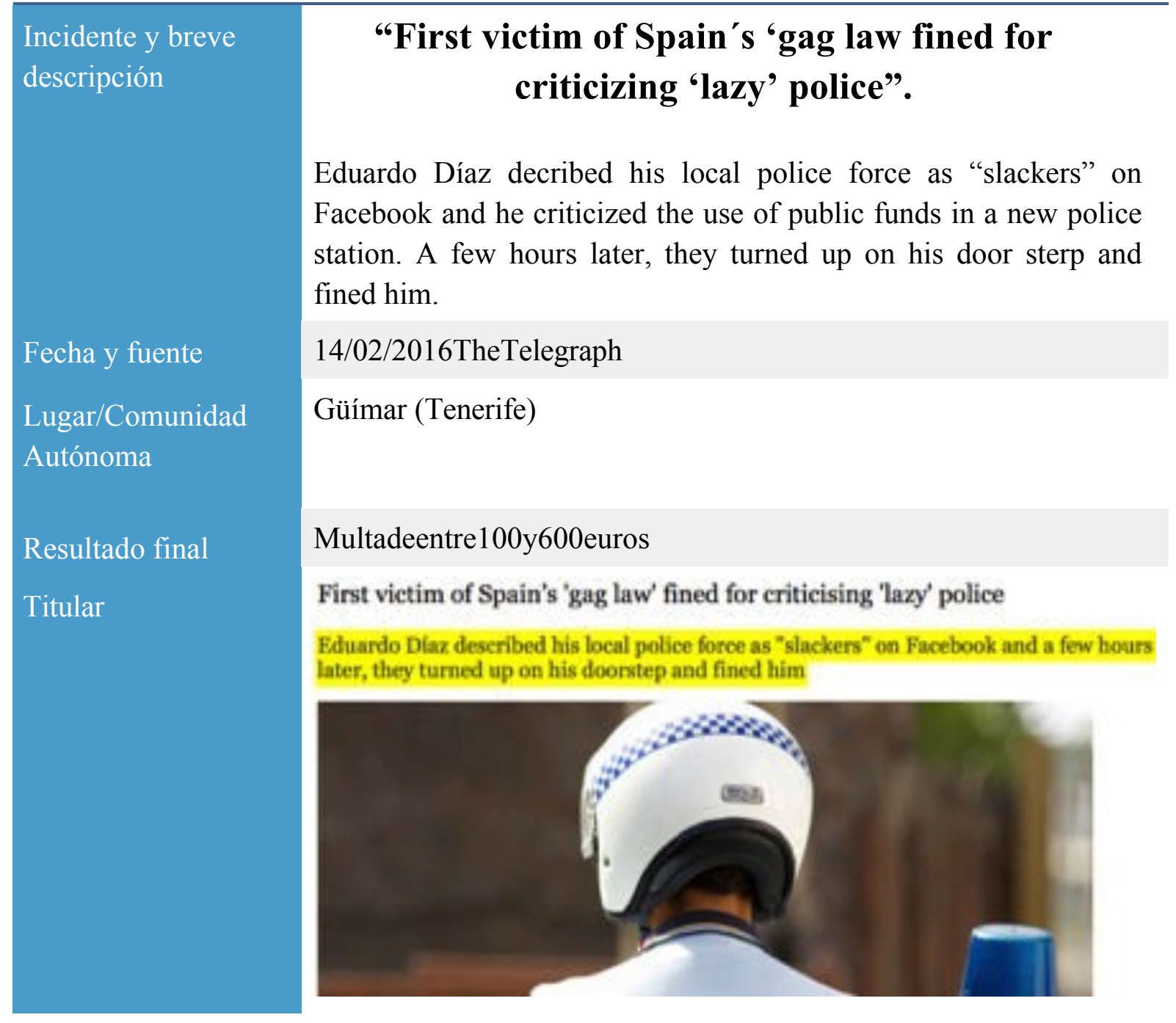




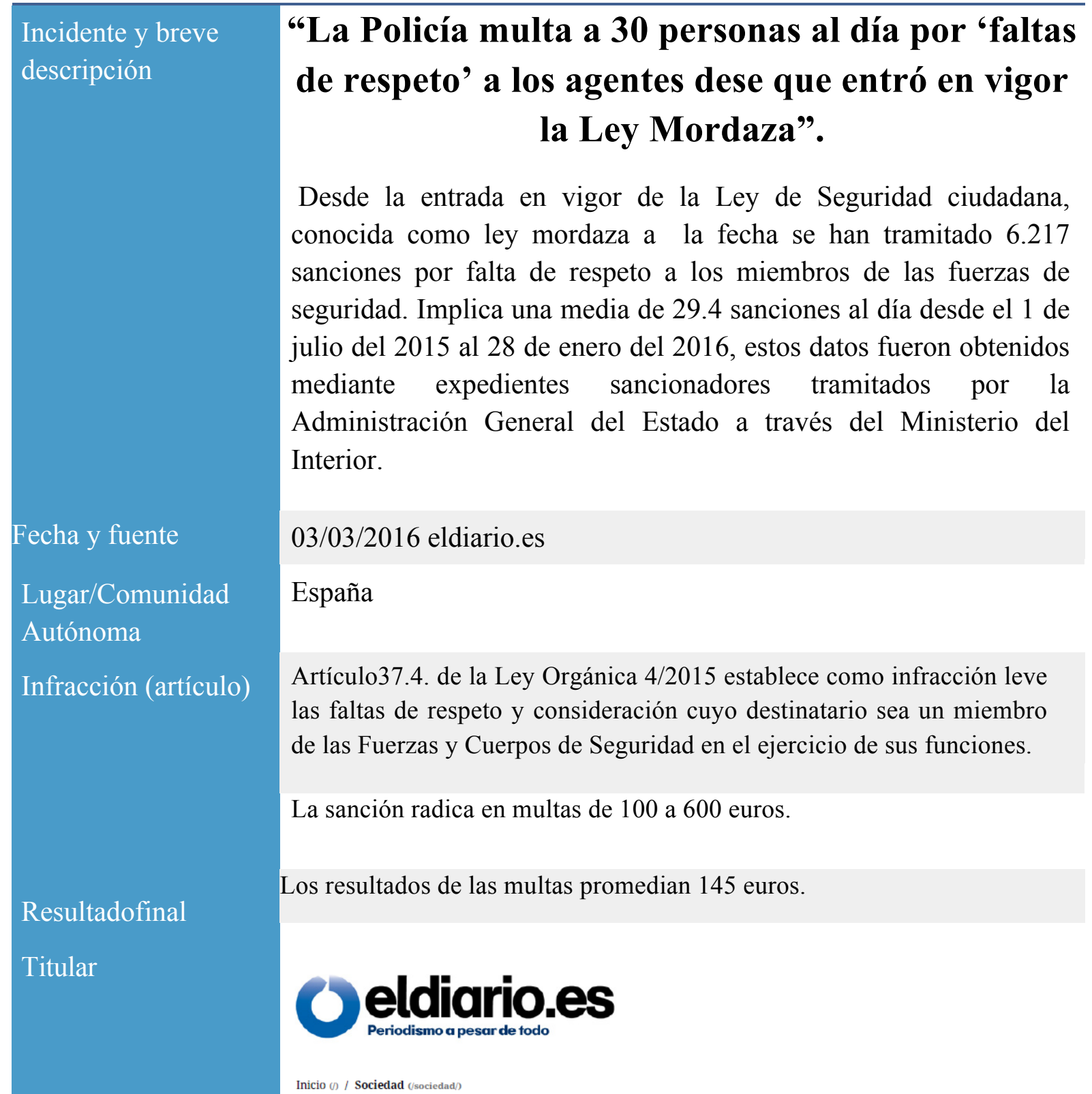

La Policía multa a 30 personas al día por "faltas de respeto" a los agentes desde que entró en vigor la Ley Mordaza 
Incidente y breve

descripción

Fecha y Fuente

Lugar/Comunidad España

Autónoma

Titular
"EI J.R Mora del Hoy: el precio de la mordaza".

El periodista AxierLopez fue multado con 601 euros por publicar fotos de una operación policial.

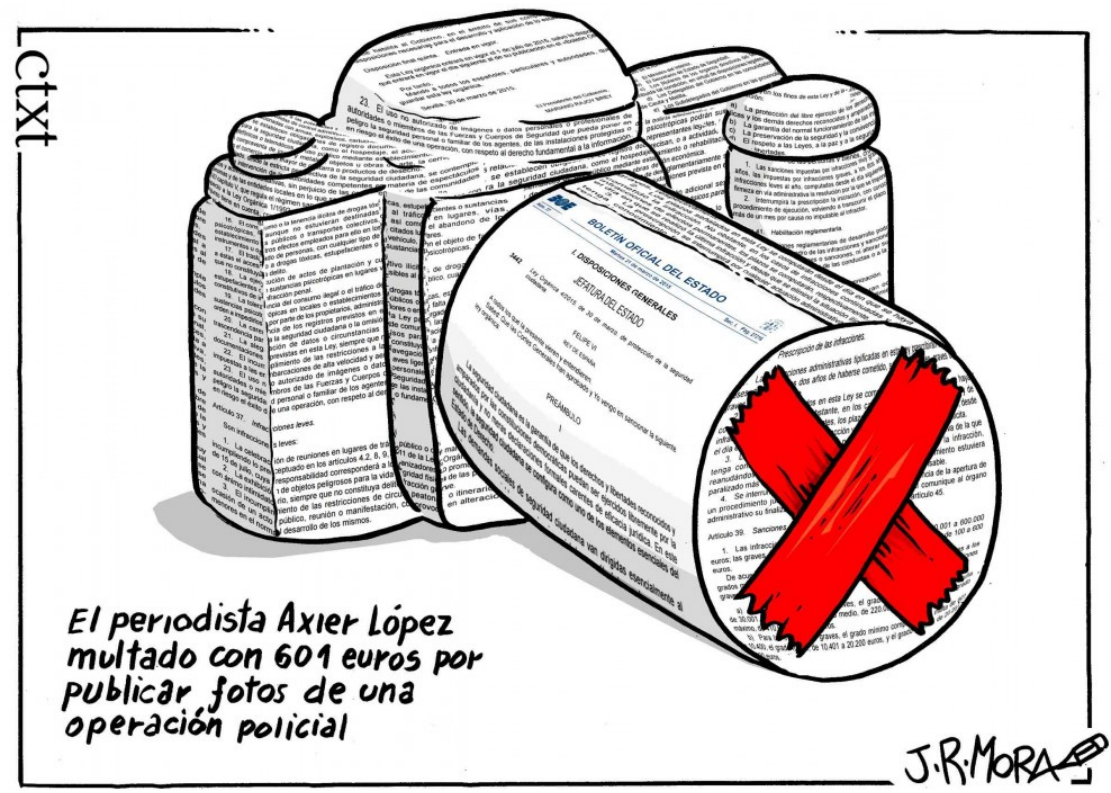

09/04/2016 CTXT.ES

\section{El J. R. Mora de hoy: el precio de la mordaza (09/04/2016)}

J. R. MORA 


\begin{abstract}
Incidente y breve descripción

Fecha y fuente

Lugar/Comunidad Autónoma

Infracción (artículo)

\section{"Es hora de hacer frente a la merma de derechos y libertades del PP".}

Cesar Montaña Lehman vocalista del grupo Def Con Dos, fue incluido en la Operación Araña ejecutada por la Guardia Civil, en las que más de 20 personas fueron detenidas como consecuencia de sus opiniones vertidas a través de distintas cuentas y en diferentes momentos en Twitter. El vocalista publicó en su cuenta tuits como "Franco, Serrano Suñer, Arias Navarro, Fraga, Blas Piñar. Si no les das lo que a Carrero Blanco, la longevidad se pone de su lado" o "Cuántos deberían seguir el vuelo de Carrero Blanco". Hace nueve meses fue detenido por un presunto delito de enaltecimiento del terrorismo del internet y al momento enfrenta 20 meses de cárcel.

\section{9/04/2016 CTXT.es}

Madrid, España.

Ley Orgánica 10/1995, de 23 de noviembre del Código Penal: Artículo578: "El enaltecimiento o la justificación públicos de los delitos comprendidos en los artículos 572 a 577 o de quienes hayan participado en su ejecución, o la realización de actos que entrañen descrédito, menosprecio o humillación de las víctimas de los delitos terroristas o de sus familiares, se castigará con la pena de prisión de uno a tres años y multa de doce a dieciocho meses. El juez también podrá acordar en la sentencia, durante el periodo de tiempo que él mismo señale, alguna o algunas de las prohibiciones previstas en el artículo 57.2. Las penas previstas en el apartado anterior se impondrán en su mitad superior cuando los hechos se hubieran llevado a cabo mediante la difusión de servicios o contenidos accesibles al público a través de medios de comunicación, internet, o por medio de servicios de comunicaciones electrónicas o mediante el uso de tecnologías de la información”.
\end{abstract}

Resultadofinal

Titular

El fiscal pide 20 meses de cárcel para el acusado.

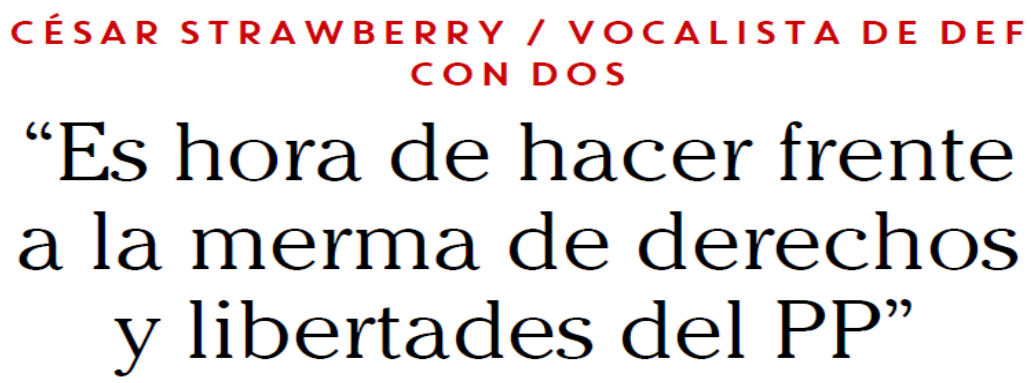




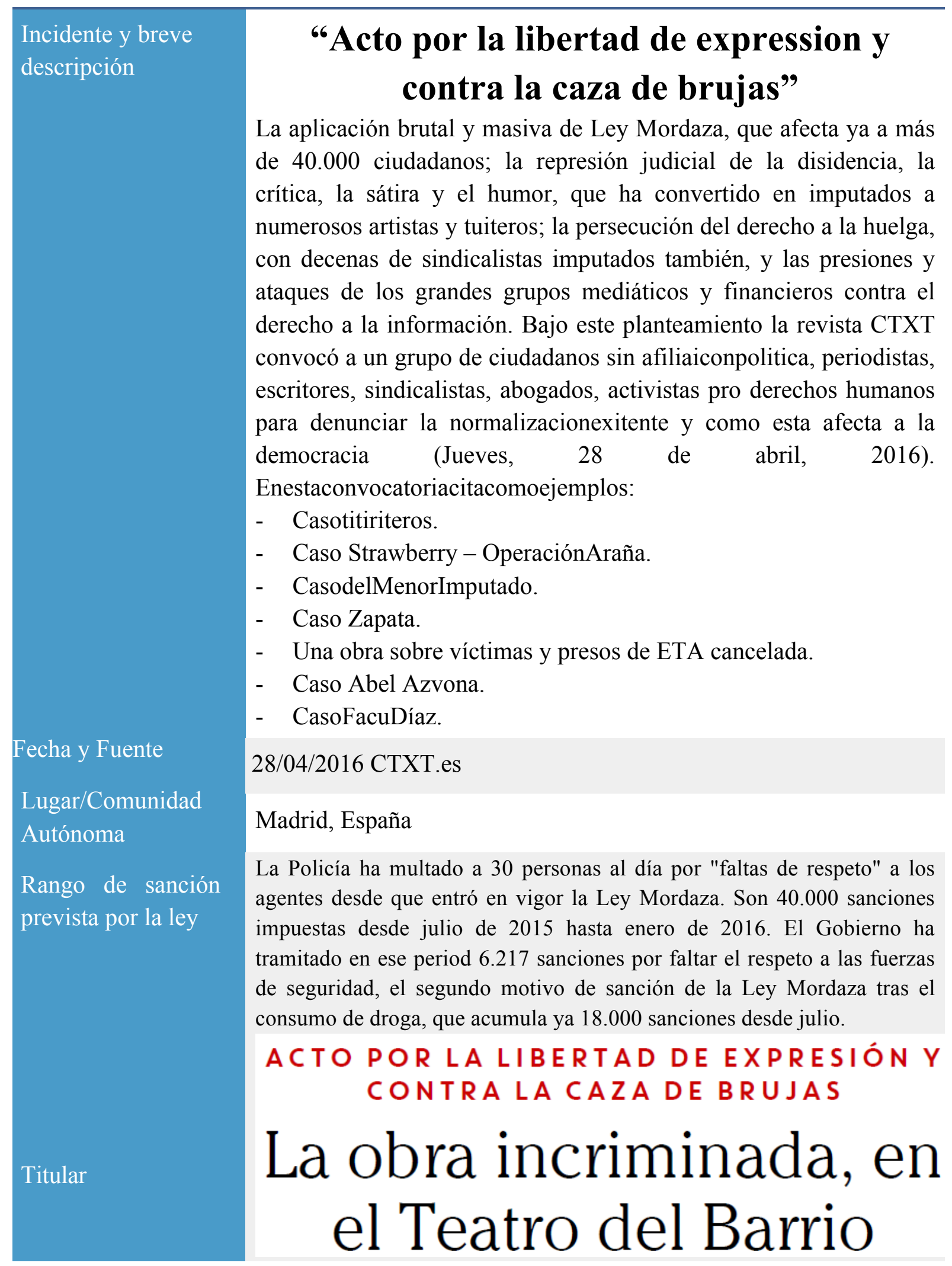




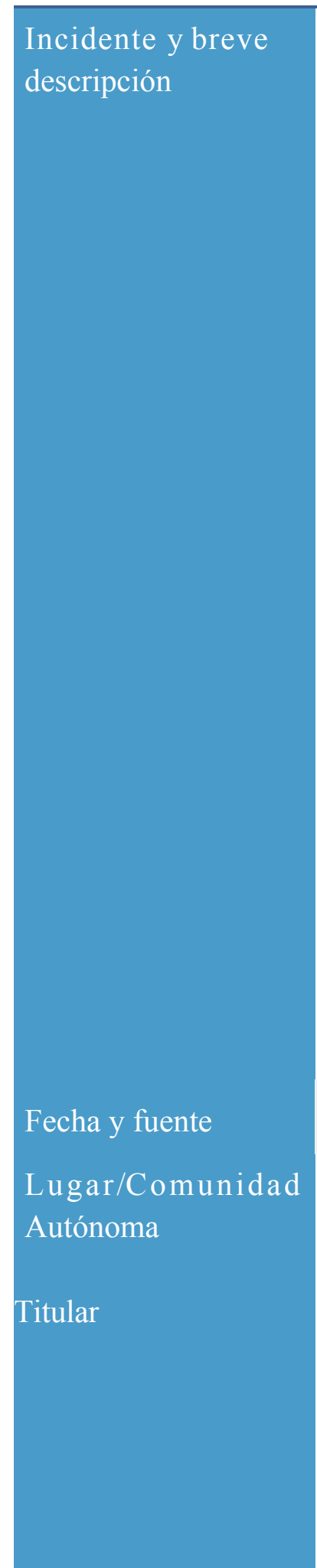

\section{"Informe Annual de la Profesión periodística 2015".}

El estudio de la APM ofrece cifras y datos sobre la situación de los medios y los profesionales. El "Informe Anual de la Profesión Periodística 2015", editado por la Asociación de la Prensa de Madrid (APM), advierte en su estudio de la devaluación de los salarios base de los periodistas españoles con convenio colectivo entre los años 2010 y 2015. En los últimos años factores como la economia, la tecnología y otros han devaluado el papel del periodista como mediador de la información. Por su parte, el gobierno ha impuesto trabas legales al ejercicio de su trabajo en la aplicación de la vigente Ley de Seguridad ciudadana, misma que ha agravado aún mas la labor de comunicar ante el temor de una sanción.

\section{Tabla 37 Causas de la poca confianza de los} usuarios en la información de los medios

\section{5}

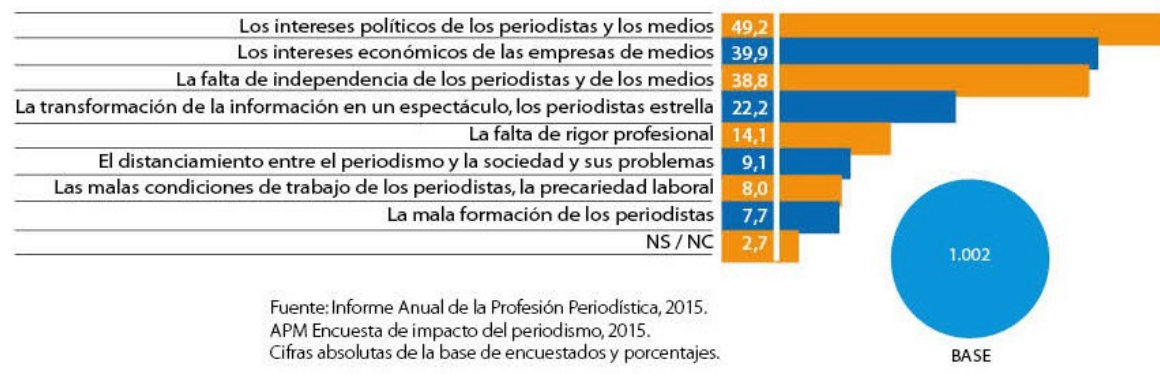

04/05/2016 CTXT.es

España.

\section{Informe Anual de la Profesión Periodística 2015}




\section{Interactive map of news}

This work is asynchronous therefore, it is not possible to perform an ongoing updating of the cases detected, from Context and Action (CTXT.es) has launched this initiative which is very useful for tracking updated on the implementation of the law.

For futher information visit: https://CTXT.es.es/es/20150715/politica/1827/España.htm 